\author{
University of São Paulo \\ "Luiz de Queiroz" College of Agriculture
}

\title{
Comprehensive analysis of sugarcane (Saccharum spp) gene expression changes in response to drought and re-watering conditions
}

\section{Danielle Izilda Rodrigues da Silva}


Danielle Izilda Rodrigues da Silva

Bachelor and Licentiate in Biological Sciences

Comprehensive analysis of sugarcane (Saccharum spp) gene expression changes in response to drought and re-watering conditions

Advisor:

Profa. Dra. GLAUCIA MENDES SOUZA

Thesis presented to obtain the degree of Doctor in Science.

Program: International Plant Cell and Molecular Biology

\section{Piracicaba}


RESUMO

\title{
Análise global das mudanças na expressão gênica em cana-de-açúcar (Saccharum spp) em resposta às condições de seca e reidratação
}

\begin{abstract}
A exaustão dos combustíveis fósseis juntamente com os efeitos não desejáveis de seu uso, tonaram a cana-de-açúcar uma cultura atrativa para o mercado de biocombustíveis, aumentando a sua importância econômica e ambiental. A posição do Brasil como o principal produtor de cana-de-açúcar e a necessidade de expandir a área plantada para regiões com condições menos favoráveis, tornam o estudo da seca, um dos principais estresses abióticos que afetam a produtividade da cultura, essencial para o futuro do Brasil como o principal exportador dessa comoditie. Este trabalho tem o objetivo de fornecer uma análise global das respostas da cana-de-açúcar à seca, tanto em nível fisiológico quanto molecular. Para isso, foram seguidas quatro estratégias. Primeiro foi realizada uma análise da fisiologia e do transcriptoma (microarranjo) de plantas de cana-de-açúcar cultivadas em casa de vegetação e estressadas por três períodos diferentes ( 4 dias de estresse, 6 dias de estresse e reidratação). Os tecidos analisados foram folha e raiz. Segundo, com o objetivo de identificar diferentes genes e novos padrões de expressão, foi realizada a análise de RNA-Seq em tecidos de folha e raiz utilizando a condição mais discrepante identificada pelo microarray; terceiro, foi feita a análise de um experimento de progressão da seca por meio da fisiologia e qRT-PCR usando genes candidatos selecionados. A quarta estratégia foi a construção de redes de co-expressão objetivando detectar módulos de genes relacionados à resposta a seca. As análises de fisiologia mostraram que as plantas estavam sob estresse moderado a severo com diminuição de até $97 \%$ na fotossíntese. Os dados de microarray levaram à identificação de 7.867 SAS únicos com diferença de razão de expressão maior que 2 ou menor que 0,5 , e 575 SAS únicos diferencialmente expressos. A análise das sequencias identificadas permitiu a observação de que em folhas, depois de 4 dias de estresse, há basicamente a transdução dos sinais obtidos a partir do ambiente, enquanto depois de 6 dias e após a reidratação há uma resposta mais funcional da planta, com a última conduzindo o metabolismo de volta à homeostase. No caso das raízes foi observado uma resposta similar, porém, as raízes demoram mais tempo para voltar à condição inicial, de forma diversos genes continuam reprimidos mesmo após a reidratação. Há ainda rotas metabólicas, como o Biosíntese de Fenilpropanoides, que apresentam perfis opostos nos tecidos analisados, sendo ativada em um e reprimida no outro. Além disso, enquanto em folhas há uma restrição na fotossíntese, em raízes parece existir uma restrição no crescimento. A análise de novo do RNA-Seq mostrou 28.240 "features" diferencialmente expressos em folhas e 7.435 em raízes, enquanto a utilização do genoma de referência (dados não publicados) identificou 38.317 genes diferencialmente expressos em folha e 7.649 em raiz, sendo que a análise das rotas do KEGG indicam que o ABA tem um papel principal nas respostas à seca em ambos os tecidos, no entanto em folhas existe uma interação entre fitohormônios. $\mathrm{O}$ experimento de progressão da seca confirma os resultados obtidos a partir do microarranjo e mostram que quando o estresse é severo, a expressão gênica começa à diminuir, sugerindo que a planta pode estar entrando em senescência. As análises de coexpressão permitiram a determinação de três módulos correlacionados com parâmetros de fisiologia alterados durante o estresse hídrico, e conduziram à identificação de alguns genes centrais que podem ser importantes para as respostas da cana à seca. Além disso, foi possível identificar genes que tanto pela análise de co-expressão quanto pelo qRT-PCR apresentam padrões similar de expressão. Juntos, esses resultados forneceram uma visão global das alterações que ocorrem na cana-de-açúcar em resposta ao estresse hídrico e ajudaram a obter conhecimento para seleção de genes candidatos adequados para o melhoramento genético de plantas.
\end{abstract}

Palavras-chave: Cana-de-Açúcar; Estresse Hídrico; Expressão Gênica; Transcritoma; Redes de Coexpressão 


\section{ABSTRACT \\ Comprehensive analysis of sugarcane (Saccharum spp) gene expression changes in response to drought and re-watering conditions}

The exhaustion of oil fields together with the undesirable effects of its use has turned sugarcane into an attractive crop for the biofuel market, increasing its economic and environmental importance. The position of Brazil as the world's major sugarcane producer and the need to expand the planted area to soil with less favorable conditions makes the study of drought, one of the abiotic stresses affecting the most of this crop yield, essential for the future of Brazil as the main exporter of this commodity. This work has the aim of providing a comprehensive analysis of sugarcane drought responses in the physiological and molecular levels. In order to do that we followed four strategies. First, we performed the analysis of physiology and transcriptome (microarray) of drought stressed sugarcane plants in three time points (4 days of stress, 6 days of stress and re-watering) of a greenhouse experiment. The plant material analyzed was leaves and roots. Second, aiming to identify different genes and new patterns of expression it was done the analysis of RNA-Seq from the most discrepant condition, from both leaves and roots, found by the microarray, third, we performed the analysis of a drought progression experiment through physiology and qRT-PCR of selected candidate genes and forth we built co-expression networks to detect interesting patterns. Physiology analysis showed that plants were under moderate to severe water stress with decreases of up to $97 \%$ in photosynthesis. Microarray data indentified 7,867 unique SAS with a fold change of more than 2 or less that 0.5 , and 575 unique SAS differentially expressed. The analysis of the identified sequences allowed the observation that in leaves after 4 days of stress, the plant is mostly transducing the signal from the environment, while after 6 days and after rehydration there is a more functional response of the plant, with re-watering leading the metabolism back to homeostase. In the case of roots, it was observed a similar response, however roots take longer to go back to the initial condition, since several genes are still being down-regulated even after re-watering. There are also pathways presenting an opposite pattern in the analyzed tissues, being activated in one tissue but repressed in the other, such as Phenylpropanoid Biosynthesis pathway. Furthermore, while in leaves there is a restriction on photosynthesis, on roots it seems to be a restriction on growth. RNA-Seq de novo assembly showed 28,240 differentially expressed features in leaves and 7,435 in roots, while using the reference genome (unpublished data) it was possible to identify 38,317 differentially expressed genes in leaves and 7,649 in roots, and the analysis of KEGG pathways indicate that $\mathrm{ABA}$ has a major role in both leaves and roots responses to drought, but in leaves there is an interplay of phytohormones. Drought progression experiment confirms the results obtained from microarray and shows that when stress is extreme, gene expression starts to decrease, suggesting the plant might be entering in senescence. Co-expression analysis allowed the determination of three modules correlated with physiological parameters altered during water stress, and lead to the identification of some possible hub genes that may be important for sugarcane responses to drought. Furthermore, it was possible to identify genes that through both co-expression and qRT-PCR analysis had similar patterns of expression. Altogether, these results give us a comprehensive view of the alterations in sugarcane responses to water stress and helped us gain insight for defining better suited candidate genes for plant breeding.

Keywords: Sugarcane; Water Stress; Gene Expression; Transcriptome; Co-Expression Network 


\section{INTRODUCTION}

Sugarcane (Saccharum spp.) is a perennial, tropical or subtropical grass that belongs to the Poaceae family and has been cultivated and bred for thousands of years (MING et al., 2006). It is a C4 grass whose economic and environmental importance has been growing (AMALRAJ et al., 2010; LEMBKE et al., 2012; ROCHA et al., 2007; ZHOU et al., 2012), especially because it is a highly competitive source of sucrose and ethanol in tropical and subtropical countries (CALSA; FIGUEIRA, 2007). This crop contributes to about $60 \%$ of the white sugar produced in the whole world, being its biomass still used to produce bioethanol and generate electricity (AMALRAJ et al., 2010).

The importance of the sugarcane agroindustry has been growing due to the decreasing oil reserves and high prices of petroleum allied to the increase of the population conscience regarding the environment and the undesirable effects of using fossil fuels in the balance of atmosphere carbon and in the increase of greenhouse gases emission (National Company of Supply - Conab, 2016). In this aspect, sugarcane is considered a great option for the biofuel market, in which its economic and environmental value can be exemplified by the decrease in greenhouse gases emission, lower cost for production and higher ethanol productivity, when compared with other crops, such as corn and sugar-beet (GOLDEMBERG; GUARDABASSI, 2010).

Brazil is the main world producer of sugarcane, with a planted area of about 8.7 million hectares. It is responsible for more than half of the sugar commercialized in the world, and the average increase rate of production is estimated to reach up to $3.25 \%$ by 2018/19 (Ministry of Agriculture, Livestock and Food Supply - MAPA, 2012). Therefore, the rise in the world demand for ethanol derived from renewable sources associated with the amount of arable land and the edafoclimatic conditions, has turned Brazil into a promising country for the exportation of this commodity (National Company of Supply - Conab, 2016).

In Brazil, sugarcane production is centered in the Northeast and South-central regions (Sugarcane Industry Union - ÚNICA, 2012), with the major expansion of planted area being localized in the Southeast region, especially in São Paulo state (National Company of Supply - Conab, 2012). This region is responsible for about $60.7 \%$ of sugar production and more than $60 \%$ of ethanol production in the country (National Company of Supply - Conab, 2016). However, the increasing world demand for biofuels is requiring the occupation of new tillage areas, including less favorable lands (ENDRES, 2010).

Sugarcane modern cultivars are polyploid and aneuploid clones, derived from interspecific hybridization between S. officinarum and S. spontaneum (HOARAU et al., 2001). Commercial varieties have 8 to 12 sets of the haploid genome with 100 - 130 chromosomes, and different levels of aneuploidy (MING et al., 2006). This aspect makes sugarcane a particularly challenging crop for plant breeding. Furthermore, crossing of large genomes, which suffered recent duplications in order to allow the chromosomal pairing and recombination turns each genotype of each progeny into a unique genome.

Abiotic stresses are the primary causes of crop loss worldwide, reducing average yields for most major crops by more than 50\% (RODRIGUEZ; CANALES; BORRAS-HIDALGO, 2005). These environmental constraints have also been shown to impair sugarcane productivity (ROCHA et al., 2007; SEKI et al., 2003), whose cultivation faces considerable losses due to inappropriate or unfavorable soil and climatic conditions (KIDO et al., 2012).

Water deficit constitutes one of the major stresses that affect the development of sugarcane (PRABU; THEERTHA PRASAD, 2012; SUGIHARTO et al., 2002), limiting its productivity (ROCHA et al., 2007; SEKI et al., 2003) and leading to considerable yield losses (KIDO et al., 2012). During 2014, the decrease in the rain in the southeast region, especially in the states of São Paulo and Minas Gerais, led to a harvest reduction of $8.5 \%$ compared to the 
previous season (Brazilian Sugarcane Industry Association - UNICA, 2014). Even a non-constant dry climate for a small period is capable of modifying the formation of internodes that become shorter despite not affecting the overall productivity (National Company of Supply - Conab, 2016).

Taking into account these aspects, breeding new varieties that have better water use efficiency or that are able to tolerate/resist drought has become of major importance (LI et al., 2016a) and a necessity for the future of agriculture (PRABU et al., 2011). Nevertheless, owing to its genetic complexity and polyploid nature with significant levels of chromosomal mosaicism (MENOSSI et al., 2008), breeding through conventional techniques is challenging and not sufficient anymore to develop new varieties, being necessary to build up new tools that will allow the obtainment of more tolerant or resistant varieties.

Characterization of genes underlying drought responses and elucidation of regulatory mechanisms related to sugarcane drought tolerance can be of great help to direct strategies that will ultimately lead to an increase in productivity and an expansion of the cultivated area to regions such as the northeast of Brazil, which has a dry climate due to the lack of rain (LEMBKE et al., 2012; SILVA et al., 2013a). Gene expression profiling associated to rehydration and drought responses is a way to comprehend the regulatory mechanisms that govern the tolerance and adaptation to drought (GENTILE et al., 2013; LEMBKE et al., 2012; NAKASHIMA; YAMAGUCHI-SHINOZAKI; SHINOZAKI, 2014; PERRONE et al., 2012).

The knowledge of the mechanisms underlying drought responses and its relation with carbon partition and other characteristics of interest (LEMBKE et al., 2012), such as the lignocellulose content (VEGA-SÁNCHEZ; RONALD, 2010) can also be of great help to the increase of productivity. Furthermore, improved drought tolerance is important to the development of biofuel-focused canes (energy canes - high sucrose levels, increased biomass yield and cell wall altered for enhanced saccharification) that would not compete for tillage areas with other food crops (WACLAWOVSKY et al., 2010). Altogether, this knowledge can be used to develop better breeding strategies for drought tolerance, which can sustainably reduce the impact of drought stress (MWENYE et al., 2016).

The results of our work provide a comprehensive view of the changes on sugarcane transcriptome in response to one of the major stresses affecting its yield. In order to do that, it was analyzed (a) leaf and roots tissues following not only the traditional pipeline to identify differentially expressed genes, but also the identification of unknown sugarcane genes by RNA-Seq; (b) the physiology analysis in both, specific time points and during drought progression; (c) the evaluation of the expression level of candidate genes during drought evolution in a time-course experiment and (d) a co-expression analysis using data from this work and previous works of the group. These results provide targets for plant breeding for drought tolerance, especially since rehydration had not yet been contemplated in the previous works of our group (LEMBKE et al., 2012; ROCHA et al., 2007) and physiological data was not as detailed as done in this study. Furthermore, there is an absence of studies analyzing the changes in sugarcane roots transcriptome in response to drought (KIDO et al., 2012).

Hence, this work aimed to analyze sugarcane gene regulation mechanisms involved in drought responses and to start to understand the architecture of sugarcane drought-related networks. It was intended to direct future studies about water stress sugarcane responses, providing a comprehensive view of the alterations in gene expression due to this stress imposition. 


\section{REFERENCES}

AMALRAJ, R. S. et al. Sugarcane proteomics: Establishment of a protein extraction method for 2-DE in stalk tissues and initiation of sugarcane proteome reference map. ELECTROPHORESIS, v. 31, n. 12, p. 1959-1974, 18 jun. 2010.

CALSA, T.; FIGUEIRA, A. Serial analysis of gene expression in sugarcane (Saccharum spp.) leaves revealed alternative C4 metabolism and putative antisense transcripts. Plant Molecular Biology, v. 63, n. 6, p. 745-762, 9 mar. 2007.

ENDRES, L. Photosynthesis and Water Relations in Brazilian Sugarcane. The Open Agriculture Journal, v. 4, n. 1, p. 31-37, 13 oct. 2010.

GENTILE, A. et al. Effects of drought on the microtranscriptome of field-grown sugarcane plants. Planta, v. 237, n. 3, p. 783-798, mar. 2013.

GOLDEMBERG, J.; GUARDABASSI, P. The potential for first-generation ethanol production from sugarcane. Biofuels, Bioproducts and Biorefining, v. 4, n. 1, p. 17-24, jan. 2010.

HOARAU, J.-Y. et al. Genetic dissection of a modern sugarcane cultivar (Saccharum spp.). I. Genome mapping with AFLP markers. Theoretical and Applied Genetics, v. 103, n. 1, p. 84-97, 1 jul. 2001.

KIDO, É. A. et al. New Insights in the Sugarcane Transcriptome Responding to Drought Stress as Revealed by Supersage. The Scientific World Journal, v. 2012, p. 1-14, 2012.

LEMBKE, C. G. et al. Identification of sense and antisense transcripts regulated by drought in sugarcane. Plant Molecular Biology, v. 79, n. 4-5, p. 461-477, jul. 2012.

LI, C. et al. Differential expression profiles and pathways of genes in sugarcane leaf at elongation stage in response to drought stress. Scientific Reports, v. 6, n. 1, sept. 2016a.

MENOSSI, M. et al. Sugarcane Functional Genomics: Gene Discovery for Agronomic Trait Development. International Journal of Plant Genomics, v. 2008, p. 1-11, 2008.

MING, R. et al. Sugarcane Improvement through Breeding and Biotechnology. In: JANICK, J. (Ed.). . Plant breeding reviews. New York; Chichester: Wiley, ., 2006.

Ministry of Agriculture, Livestock and Food Supply - MAPA - MAPA. Available at: < http://www.agricultura.gov.br/vegetal/culturas/cana-de-acucar/saiba-mais>. Access at: 03 jul. 2012.

MWENYE, O. J. et al. The role of proline and root traits on selection for drought-stress tolerance in soybeans: a review. South African Journal of Plant and Soil, v. 33, n. 4, p. 245-256, oct. 2016.

NAKASHIMA, K.; YAMAGUCHI-SHINOZAKI, K.; SHINOZAKI, K. The transcriptional regulatory network in the drought response and its crosstalk in abiotic stress responses including drought, cold, and heat. Frontiers in Plant Science, v. 5, 16 may 2014.

National Company of Supply. Acompanhamento da Safra Brasileira: Cana-de-Açúcar. Primeiro levantamento, abril/2012. Brasília: Conab, 2012. 19 p.

National Company of Supply. Acompanhamento da Safra Brasileira: Cana-de-Açúcar. Segundo levantamento, agosto/2016. Brasília: Conab, 2016. 72 p.

PERRONE, I. et al. Recovery from water stress affects grape leaf petiole transcriptome. Planta, v. 235, n. 6, p. 1383 1396, jun. 2012.

PRABU, G. et al. Identification of Water Deficit Stress Upregulated Genes in Sugarcane. Plant Molecular Biology Reporter, v. 29, n. 2, p. 291-304, jun. 2011. 
PRABU, G.; THEERTHA PRASAD, D. Functional characterization of sugarcane MYB transcription factor gene promoter (PScMYBAS1) in response to abiotic stresses and hormones. Plant Cell Reports, v. 31, n. 4, p. 661669, april. 2012.

ROCHA, F. R. et al. Signal transduction-related responses to phytohormones and environmental challenges in sugarcane. BMC Genomics, v. 8, n. 1, p. 71, 2007.

RODRIGUEZ, M.; CANALES, E.; BORRAS-HIDALGO, O. Molecular aspects of abiotic stress in plants. [s.l: s.n.]. V. 22

SEKI, M. et al. Molecular responses to drought, salinity and frost: common and different paths for plant protection. Current Opinion in Biotechnology, v. 14, n. 2, p. 194-199, april. 2003.

SILVA, M. DE A. et al. Photosynthetic capacity and water use efficiency in sugarcane genotypes subject to water deficit during early growth phase. Brazilian Archives of Biology and Technology, v. 56, n. 5, p. 735-748, oct. $2013 \mathrm{a}$.

SUGIHARTO, B. et al. Identification and characterization of a gene encoding drought-inducible protein localizing in the bundle sheath cell of sugarcane. Plant \& Cell Physiology, v. 43, n. 3, p. 350-354, mar. 2002.

SUGARCANE INDUSTRY UNION - ÚNICA. Available at: $<$ http://www.unica.com.br/content/show.asp?cntCode= $\{$ D6C39D36-69BA-458D-A95C-815C87E4404D $\}>$. Access at: 03 jul. 2014.

VEGA-SÁNCHEZ, M. E.; RONALD, P. C. Genetic and biotechnological approaches for biofuel crop improvement. Current Opinion in Biotechnology, v. 21, n. 2, p. 218-224, april. 2010.

WACLAWOVSKY, A. J. et al. Sugarcane for bioenergy production: an assessment of yield and regulation of sucrose content. Plant Biotechnology Journal, v. 8, n. 3, p. 263-276, april. 2010.

ZHOU, G. et al. Proteomic Analysis of Osmotic Stress-Responsive Proteins in Sugarcane Leaves. Plant Molecular Biology Reporter, v. 30, n. 2, p. 349-359, 1 april. 2012 


\section{REFERENCES}

AGARWAL, M.; ZHU, J.-K. Integration of Abiotic Stress Signaling Pathways. In: JENKS, M. A.; HASEGAWA, P. M. (Eds.). . Plant Abiotic Stress. Oxford, UK: Blackwell Publishing Ltd, 2005. p. 215-247.

AHMAD, P. et al. Jasmonates: Multifunctional Roles in Stress Tolerance. Frontiers in Plant Science, v. 7, 15 jun. 2016.

ARABZADEH, N. The Effect of Drought Stress on Soluble Carbohydrates (Sugars) in Two Species of Haloxylon persicum and Haloxylon aphyllum. Asian Journal of Plant Sciences, v. 11, n. 1, p. 44-51, 1 jan. 2012.

AROCA, R. (ED.). Plant responses to drought stress: from morphological to molecular features. Heidelberg: New York: Springer, 2012.

AROCA, R.; PORCEL, R.; RUIZ-LOZANO, J. M. Regulation of root water uptake under abiotic stress conditions. Journal of Experimental Botany, v. 63, n. 1, p. 43-57, 1 jan. 2012.

ARTSCHWAGER, E.; BRANDES, E. W. Sugarcane (Saccharum officinarum L): origin, classification, characteristics, and descriptions of representative clones isbn. [s.l: s.n.].

ASRAR, A.-W. A.; ELHINDI, K. M. Alleviation of drought stress of marigold (Tagetes erecta) plants by using arbuscular mycorrhizal fungi. Saudi Journal of Biological Sciences, v. 18, n. 1, p. 93-98, jan. 2011.

AZUAJE, F. J. Selecting biologically informative genes in co-expression networks with a centrality score. Biology Direct, v. 9, n. 1, p. 12, 2014.

BASU, S. et al. Plant adaptation to drought stress. F1000Research, v. 5, 30 jun. 2016.

BHASKARA, G. B.; YANG, T.-H.; VERSLUES, P. E. Dynamic proline metabolism: importance and regulation in water limited environments. Frontiers in Plant Science, v. 6, 25 jun. 2015.

BOHNERT, H. J.; SHEN, B. Transformation and compatible solutes. Scientia Horticulturae, v. 78, n. 1-4, p. 237260, nov. 1998.

BRAY, E. A.; BAILEY-SERRES, J.; WERETILNYK, E. Responses to Abiotic Stresses. In: BUCHANAN, B. B. et al. (Eds.). . Biochemistry \& molecular biology of plants. 7. Reprint. ed. Rockville, Md: American Soc. of Plant Physiologists, 2000.

CHAMOLI, S.; VERMA, A. K. Targeting of Metabolic Pathways for Genetic Engineering to Combat Abiotic Stress Tolerance in Crop Plants. In: GAUR, R. K.; SHARMA, P. (Eds.). . Approaches to Plant Stress and their Management. New Delhi: Springer India : Imprint: Springer, 2014.

CHENG, M.-C. et al. The Arabidopsis ETHYLENE RESPONSE FACTOR1 Regulates Abiotic Stress-Responsive Gene Expression by Binding to Different cis-Acting Elements in Response to Different Stress Signals. PLANT PHYSIOLOGY, v. 162, n. 3, p. 1566-1582, 1 jul. 2013.

CHIMENTI, C. A.; MARCANTONIO, M.; HALL, A. J. Divergent selection for osmotic adjustment results in improved drought tolerance in maize (Zea mays L.) in both early growth and flowering phases. Field Crops Research, v. 95, n. 2, p. 305-315, 15 feb. 2006.

COLEBROOK, E. H. et al. The role of gibberellin signalling in plant responses to abiotic stress. Journal of Experimental Biology, v. 217, n. 1, p. 67-75, 1 jan. 2014.

CRUZ DE CARVALHO, M. H. Drought stress and reactive oxygen species. Plant Signaling \& Behavior, v. 3, n. 3, p. 156-165, mar. 2008.

DANIELS, J.; ROACH, B. T. Taxonomy and evolution. In: HEINZ, D. J. (Ed.). . Sugarcane improvement through breeding. Developments in crop science. Amsterdam; New York: Elsevier, 1987. 
DAVIES, P. J. Plant Hormones and their Role in Plant Growth and Development. Dordrecht: Springer Netherlands, 1987.

DE MICCO, V.; ARONNE, G. Morpho-Anatomical Traits for Plant Adaptation to Drought. In: AROCA, R. (Ed.). .

Plant responses to drought stress: from morphological to molecular features. Berlin: Springer, 2012.

DONG, C.-H. et al. Gene expression profiling of Sinapis alba leaves under drought stress and rewatering growth conditions with Illumina deep sequencing. Molecular Biology Reports, v. 39, n. 5, p. 5851-5857, may 2012.

DU, H.; LIU, H.; XIONG, L. Endogenous auxin and jasmonic acid levels are differentially modulated by abiotic stresses in rice. Frontiers in Plant Science, v. 4, 9 oct. 2013.

FAROOQ, M. et al. Physiological Role of Exogenously Applied Glycinebetaine to Improve Drought Tolerance in Fine Grain Aromatic Rice ( Oryza sativa L.). Journal of Agronomy and Crop Science, v. 194, n. 5, p. 325-333, oct. 2008.

FAROOQ, M. et al. Improving the Drought Tolerance in Rice ( Oryza sativa L.) by Exogenous Application of Salicylic Acid. Journal of Agronomy and Crop Science, v. 195, n. 4, p. 237-246, aug. 2009.

FAROOQ, M. et al. Drought Stress in Plants: An Overview. In: AROCA, R. (Ed.). . Plant Responses to Drought Stress. Berlin, Heidelberg: Springer Berlin Heidelberg, 2012. p. 1-33.

FERREIRA, T. H. S. et al. Sugarcane Water Stress Tolerance Mechanisms and Its Implications on Developing Biotechnology Solutions. Frontiers in Plant Science, v. 8, 23 jun. 2017.

FIGUEIRA, T. R. et al. A BAC library of the SP80-3280 sugarcane variety (saccharum sp.) and its inferred microsynteny with the sorghum genome. BMC Research Notes, v. 5, n. 1, p. 185, 2012.

FINKELSTEIN, R. R.; GAMPALA, S. S. L.; ROCK, C. D. Abscisic Acid Signaling in Seeds and Seedlings. The Plant Cell Online, v. 14, n. suppl 1, p. S15-S45, 1 may 2002.

FUJITA, Y. et al. ABA-mediated transcriptional regulation in response to osmotic stress in plants. Journal of Plant Research, v. 124, n. 4, p. 509-525, jul. 2011.

GARG, A. K. et al. Trehalose accumulation in rice plants confers high tolerance levels to different abiotic stresses. Proceedings of the National Academy of Sciences, v. 99, n. 25, p. 15898-15903, 10 dcz. 2002.

GENTILE, A. et al. Effects of drought on the microtranscriptome of field-grown sugarcane plants. Planta, v. 237, n. 3, p. 783-798, mar. 2013.

HANIN, M. et al. Plant dehydrins and stress tolerance: versatile proteins for complex mechanisms. Plant Signaling \& Behavior, v. 6, n. 10, p. 1503-1509, oct. 2011.

HARA, M. et al. Abiotic Stress and Role of Salicylic Acid in Plants. In: AHMAD, P.; PRASAD, M. N. V. (Eds.). . Abiotic stress responses in plants: metabolism, productivity and sustainability. New York: Springer, 2012.

HARB, A. et al. Molecular and Physiological Analysis of Drought Stress in Arabidopsis Reveals Early Responses Leading to Acclimation in Plant Growth. PLANT PHYSIOLOGY, v. 154, n. 3, p. 1254-1271, 1 nov. 2010.

HAYAT, S. et al. Role of proline under changing environments: A review. Plant Signaling \& Behavior, v. 7, n. 11, p. 1456-1466, nov. 2012.

INGRAM, J.; BARTELS, D. THE MOLECULAR BASIS OF DEHYDRATION TOLERANCE IN PLANTS. Annual Review of Plant Physiology and Plant Molecular Biology, v. 47, n. 1, p. 377-403, jun. 1996.

ISKANDAR, H. M. et al. Identification of drought-response genes and a study of their expression during sucrose accumulation and water deficit in sugarcane culms. BMC Plant Biology, v. 11, n. 1, p. 12, 2011.

JAMES, G. (ED.). Sugarcane. 2nd ed ed. Oxford: Blackwell Science, 2004. 
JOSHI, R. et al. Transcription Factors and Plants Response to Drought Stress: Current Understanding and Future Directions. Frontiers in Plant Science, v. 7, 14 jul. 2016.

KAHLAOUI, B. et al. Brassinosteroids and drought tolerance in plants. In: AHMAD, P. (Ed.). . Water stress and crop plants: a sustainable approach. Chichester, West Sussex, UK: John Wiley \& Sons, Ltd, 2016.

KAKUMANU, A. et al. Effects of Drought on Gene Expression in Maize Reproductive and Leaf Meristem Tissue Revealed by RNA-Seq. PLANT PHYSIOLOGY, v. 160, n. 2, p. 846-867, 1 oct. 2012.

KAUR, G.; ASTHIR, B. Molecular responses to drought stress in plants. Biologia Plantarum, v. 61, n. 2, p. 201209, 1 jun. 2017.

KHAN, M. I. R. et al. Salicylic acid-induced abiotic stress tolerance and underlying mechanisms in plants. Frontiers in Plant Science, v. 6, 30 jun. 2015.

KIANI, S. P. et al. Genetic analysis of plant water status and osmotic adjustment in recombinant inbred lines of sunflower under two water treatments. Plant Science, v. 172, n. 4, p. 773-787, april. 2007.

KIDO, É. A. et al. New Insights in the Sugarcane Transcriptome Responding to Drought Stress as Revealed by Supersage. The Scientific World Journal, v. 2012, p. 1-14, 2012.

KOSOVÃ $;$, K.; VÃ-TÃ $\tilde{M}_{i} \tilde{A}_{j} S$, P.; PRÃ $\tilde{A}_{j} I L$, I. T. Wheat and barley dehydrins under cold, drought, and salinity â€“ what can LEA-II proteins tell us about plant stress response? Frontiers in Plant Science, v. 5, 9 jul. 2014.

LANGFELDER, P.; HORVATH, S. WGCNA: an R package for weighted correlation network analysis. BMC Bioinformatics, v. 9, n. 1, p. 559, 2008.

LEE, S. -J. et al. DREB2C Interacts with ABF2, a bZIP Protein Regulating Abscisic Acid-Responsive Gene Expression, and Its Overexpression Affects Abscisic Acid Sensitivity. PLANT PHYSIOLOGY, v. 153, n. 2, p. 716-727, 1 jun. 2010.

LEMBKE, C. G. et al. Identification of sense and antisense transcripts regulated by drought in sugarcane. Plant Molecular Biology, v. 79, n. 4-5, p. 461-477, jul. 2012.

LENKA, S. K. et al. Comparative analysis of drought-responsive transcriptome in Indica rice genotypes with contrasting drought tolerance: Drought-responsive transcriptome analysis in rice. Plant Biotechnology Journal, v. 9, n. 3, p. 315-327, april. 2011.

LEUNG, J.; GIRAUDAT, J. ABSCISIC ACID SIGNAL TRANSDUCTION. Annual Review of Plant Physiology and Plant Molecular Biology, v. 49, n. 1, p. 199-222, jun. 1998.

LI, Y. C. et al. Comparative analysis of water stress-responsive transcriptomes in drought-susceptible and -tolerant wheat (Triticum aestivum L.). Journal of Plant Biology, v. 55, n. 5, p. 349-360, 1 oct. 2012.

MA, Y. et al. Regulators of PP2C phosphatase activity function as abscisic acid sensors. Science (New York, N.Y.), v. 324, n. 5930, p. 1064-1068, 22 may 2009.

MARCOLINO-GOMES, J. et al. Expression Patterns of GmAP2/EREB-Like Transcription Factors Involved in Soybean Responses to Water Deficit. PLoS ONE, v. 8, n. 5, p. e62294, 7 may 2013.

MATTOS, L. M.; MORETTI, C. L. Oxidative Stress in Plants Under Drought Conditions and the Role of Different Enzymes. Enzyme Engineering, v. 5, n. 1, 2016.

MCCUE, K.; HANSON, A. Drought and salt tolerance: towards understanding and application. Trends in Biotechnology, v. 8, p. 358-362, 1990.

MILLER, G. et al. Reactive oxygen species homeostasis and signalling during drought and salinity stresses. Plant, Cell \& Environment, v. 33, n. 4, p. 453-467, april. 2010. 
MILlER, J. D.; GILBERT, R. A. Sugarcane Botany: A Brief ViewInstitute of Food and Agricultural Sciences, , 2009.

MING, R. et al. Sugarcane Improvement through Breeding and Biotechnology. In: JANICK, J. (Ed.). . Plant breeding reviews. New York; Chichester: Wiley, ., 2006.

MIRZAEI, M. et al. Differential regulation of aquaporins, small GTPases and V-ATPases proteins in rice leaves subjected to drought stress and recovery. PROTEOMICS, v. 12, n. 6, p. 864-877, mar. 2012.

MIYASHITA, K. et al. Recovery responses of photosynthesis, transpiration, and stomatal conductance in kidney bean following drought stress. Environmental and Experimental Botany, v. 53, n. 2, p. 205-214, april. 2005.

MOHAMMADKHANI, N.; HEIDARI, R.; MOHAMMADKHANI, N. Drought-induced accumulation of soluble sugars and proline in two maize varieties. 1 jan. 2008.

MOUMENI, A. et al. Comparative analysis of root transcriptome profiles of two pairs of drought-tolerant and susceptible rice near-isogenic lines under different drought stress. BMC Plant Biology, v. 11, n. 1, p. 174, 2011.

MÜLLER, M.; MUNNÉ-BOSCH, S. Ethylene Response Factors: A Key Regulatory Hub in Hormone and Stress Signaling. Plant Physiology, v. 169, n. 1, p. 32-41, sept. 2015.

MWENYE, O. J. et al. The role of proline and root traits on selection for drought-stress tolerance in soybeans: a review. South African Journal of Plant and Soil, v. 33, n. 4, p. 245-256, out. 2016.

NAKASHIMA, K. et al. NAC transcription factors in plant abiotic stress responses. Biochimica et Biophysica Acta (BBA) - Gene Regulatory Mechanisms, v. 1819, n. 2, p. 97-103, feb. 2012.

NAKASHIMA, K.; YAMAGUCHI-SHINOZAKI, K.; SHINOZAKI, K. The transcriptional regulatory network in the drought response and its crosstalk in abiotic stress responses including drought, cold, and heat. Frontiers in Plant Science, v. 5, 16 may 2014.

NARUSAKA, Y. et al. Interaction between two cis-acting elements, ABRE and DRE, in ABA-dependent expression of Arabidopsis rd29A gene in response to dehydration and high-salinity stresses. The Plant Journal, v. 34, n. 2, p. 137-148, april. 2003.

NISHIYAMA JR, M. Y. et al. The SUCEST-FUN regulatory network database: Designing an energy grass. [s.l: s.n.]. v. 114

NOCTOR, G.; MHAMDI, A.; FOYER, C. H. The Roles of Reactive Oxygen Metabolism in Drought: Not So Cut and Dried. PLANT PHYSIOLOGY, v. 164, n. 4, p. 1636-1648, 1 april. 2014.

NOCTOR, G.; MHAMDI, A.; FOYER, C. H. Oxidative stress and antioxidative systems: recipes for successful data collection and interpretation. Plant, Cell \& Environment, v. 39, n. 5, p. 1140-1160, may 2016.

NORTH, G. B.; NOBEL, P. S. Drought-induced changes in hydraulic conductivity and structure in roots of Ferocactus acanthodes and Opuntia ficus-indica. New Phytologist, v. 120, n. 1, p. 9-19, jan. 1992.

NXELE, X.; KLEIN, A.; NDIMBA, B. K. Drought and salinity stress alters ROS accumulation, water retention, and osmolyte content in sorghum plants. South African Journal of Botany, v. 108, p. 261-266, jan. 2017.

PAPINI-TERZI, F. S. et al. Transcription profiling of signal transduction-related genes in sugarcane tissues. DNA research: an international journal for rapid publication of reports on genes and genomes, v. 12, n. 1, p. 2738, 28 feb. 2005.

PAPINI-TERZI, F. S. et al. Sugarcane genes associated with sucrose content. BMC Genomics, v. 10, n. 1, p. 120, 2009. 
PARENT, B. et al. Drought and Abscisic Acid Effects on Aquaporin Content Translate into Changes in Hydraulic Conductivity and Leaf Growth Rate: A Trans-Scale Approach. PLANT PHYSIOLOGY, v. 149, n. 4, p. 2000 2012, 4 feb. 2009.

PAYTON, P. et al. Examining the drought stress transcriptome in cotton leaf and root tissue. Biotechnology Letters, v. 33, n. 4, p. 821-828, april. 2011.

PÉREZ-PÉREZ, J. G. et al. Response to drought and salt stress of lemon 'Fino 49' under field conditions: Water relations, osmotic adjustment and gas exchange. Scientia Horticulturae, v. 122, n. 1, p. 83-90, sept. 2009.

PERRONE, I. et al. Recovery from water stress affects grape leaf petiole transcriptome. Planta, v. 235, n. 6, p. 1383 1396, jun. 2012.

POSPÍŠILOVÁ, J.; SYNKOVÁ, H.; RULCOVÁ, J. Cytokinins and Water Stress. Biologia Plantarum, v. 43, n. 3, p. 321-328, 1 sept. 2000.

PRABU, G. et al. Identification of Water Deficit Stress Upregulated Genes in Sugarcane. Plant Molecular Biology Reporter, v. 29, n. 2, p. 291-304, jun. 2011.

PRICE, A. H. et al. Linking drought-resistance mechanisms to drought avoidance in upland rice using a QTL approach: progress and new opportunities to integrate stomatal and mesophyll responses. Journal of Experimental Botany, v. 53, n. 371, p. 989-1004, may 2002.

PURANIK, S. et al. NAC proteins: regulation and role in stress tolerance. Trends in Plant Science, v. 17, n. 6, p. 369-381, jun. 2012.

RAGHAVENDRA, A. S. et al. ABA perception and signalling. Trends in Plant Science, v. 15, n. 7, p. 395-401, jul. 2010.

RAMACHANDRA REDDY, A.; CHAITANYA, K. V.; VIVEKANANDAN, M. Drought-induced responses of photosynthesis and antioxidant metabolism in higher plants. Journal of Plant Physiology, v. 161, n. 11, p. 11891202, nov. 2004.

RIEMANN, M. et al. Exploring Jasmonates in the Hormonal Network of Drought and Salinity Responses. Frontiers in Plant Science, v. 6, p. 1077, 2015.

ROCHA, F. R. et al. Signal transduction-related responses to phytohormones and environmental challenges in sugarcane. BMC Genomics, v. 8, n. 1, p. 71, 2007.

RODRIGUES, F. A. et al. Sugarcane genes differentially expressed during water deficit. Biologia Plantarum, v. 55, n. 1, p. 43-53, 1 mar. 2011.

RODRIGUES, F. A.; DE LAIA, M. L.; ZINGARETTI, S. M. Analysis of gene expression profiles under water stress in tolerant and sensitive sugarcane plants. Plant Science, v. 176, n. 2, p. 286-302, 1 feb. 2009.

RODRIGUEZ MILLA, M. A. et al. Glutathione peroxidase genes in Arabidopsis are ubiquitous and regulated by abiotic stresses through diverse signaling pathways. The Plant Journal: For Cell and Molecular Biology, v. 36, n. 5, p. 602-615, dec. 2003.

ROSA, M. et al. Soluble sugars: Metabolism, sensing and abiotic stress: A complex network in the life of plants. Plant Signaling \& Behavior, v. 4, n. 5, p. 388-393, may 2009.

ROUT, N. P.; SHAW, B. P. Salt tolerance in aquatic macrophytes: possible involvement of the antioxidative enzymes. Plant Science: An International Journal of Experimental Plant Biology, v. 160, n. 3, p. 415-423, 5 fev. 2001. SCARPARI, M. S.; BEAUCLAIR, E. G. F. Anatomia e botânica. In: DINARDO-MIRANDA, L.-L.; VASCONCELOS, C. M. DE; LANDELL, M. G. DE A. (Eds.). . Cana-de-açúcar. Campinas: Instituto Agronômico, 2010. p. 882. 
SEKHAR, P. N. et al. Biochemical characterization, homology modeling and docking studies of ornithine $\delta$ aminotransferase-an important enzyme in proline biosynthesis of plants. Journal of Molecular Graphics and Modelling, v. 26, n. 4, p. 709-719, nov. 2007.

SERIN, E. A. R. et al. Learning from Co-expression Networks: Possibilities and Challenges. Frontiers in Plant Science, v. 7, 8 april. 2016.

SERRAJ, R.; SINCLAIR, T. R. Osmolyte accumulation: can it really help increase crop yield under drought conditions? Plant, Cell \& Environment, v. 25, n. 2, p. 333-341, feb. 2002.

SHEN, P.; HOUR, A.; LIU, L. D. Microarray meta-analysis to explore abiotic stress-specific gene expression patterns in Arabidopsis. Botanical Studies, v. 58, n. 1, dec. 2017.

SHEN, Q. et al. The stress- and abscisic acid-induced barley gene HVA22: developmental regulation and homologues in diverse organisms. Plant Molecular Biology, v. 45, n. 3, p. 327-340, feb. 2001.

SHINOZAKI, K.; YAMAGUCHI-SHINOZAKI, K. Gene Expression and Signal Transduction in Water-Stress Response. Plant Physiology, v. 115, n. 2, p. 327-334, oct. 1997.

SHINOZAKI, K.; YAMAGUCHI-SHINOZAKI, K. Molecular responses to dehydration and low temperature: differences and cross-talk between two stress signaling pathways. Current Opinion in Plant Biology, v. 3, n. 3, p. 217-223, 2000.

SHINOZAKI, K.; YAMAGUCHI-SHINOZAKI, K. Gene networks involved in drought stress response and tolerance. Journal of Experimental Botany, v. 58, n. 2, p. 221-227, 6 nov. 2006.

SINGH, B. et al. Embracing new-generation 'omics' tools to improve drought tolerance in cereal and food-legume crops. Biologia Plantarum, v. 59, n. 3, p. 413-428, 1 sept. 2015.

SIRCAR, S.; PAREKH, N. Functional characterization of drought-responsive modules and genes in Oryza sativa: a network-based approach. Frontiers in Genetics, v. 6, 30 jul. 2015.

SMIRNOFF, N.; CUMBES, Q. J. Hydroxyl radical scavenging activity of compatible solutes. Phytochemistry, v. 28, n. 4, p. 1057-1060, jan. 1989.

SMITA, S. et al. Identification of conserved drought stress responsive gene-network across tissues and developmental stages in rice. Bioinformation, v. 9, n. 2, p. 72-78, 18 jan. 2013.

SOUZA, G. M. et al. The sugarcane signal transduction (SUCAST) catalogue: prospecting signal transduction in sugarcane. Genetics and Molecular Biology, v. 24, n. 1-4, p. 25-34, dec. 2001.

TAIZ, L. Fisiologia vegetal. Porto Alegre: Artmed, 2010.

TAUSZ, M. et al. Short-term changes in free radical scavengers and chloroplast pigments in Pinus canariensis needles as affected by mild drought stress. Journal of Plant Physiology, v. 158, n. 2, p. 213-219, jan. 2001.

TUTEJA, N. Cold, Salinity, and Drought Stress. In: HIRT, H. (Ed.). . Plant stress biology: from genomics to systems biology. 1. reprint ed. Weinheim: Wiley-Blackwell, Wiley-VCH, 2010.

Union of Bioenergy Producers - UDOP . Available at: <http://www.udop.com.br/index.php?item=caracteristicas $>$. Access at: 02 oct. 2014.

UMEZAWA, T. et al. Molecular Basis of the Core Regulatory Network in ABA Responses: Sensing, Signaling and Transport. Plant and Cell Physiology, v. 51, n. 11, p. 1821-1839, 1 nov. 2010.

VERBRUGGEN, N.; HERMANS, C. Proline accumulation in plants: a review. Amino Acids, v. 35, n. 4, p. 753-759, nov. 2008.

VERSLUES, P. E.; SHARMA, S. Proline Metabolism and Its Implications for Plant-Environment Interaction. The Arabidopsis Book, v. 8, p. e0140, jan. 2010. 
VETTORE, A. L. et al. The libraries that made SUCEST. Genetics and Molecular Biology, v. 24, n. 1-4, p. 1-7, dec. 2001.

VETTORE, A. L. Analysis and Functional Annotation of an Expressed Sequence Tag Collection for Tropical Crop Sugarcane. Genome Research, v. 13, n. 12, p. 2725-2735, 1 dec. 2003.

VISHWAKARMA, K. et al. Abscisic Acid Signaling and Abiotic Stress Tolerance in Plants: A Review on Current Knowledge and Future Prospects. Frontiers in Plant Science, v. 08, 20 feb. 2017.

WILKINSON, S. et al. Plant hormone interactions: innovative targets for crop breeding and management. Journal of Experimental Botany, v. 63, n. 9, p. 3499-3509, 1 may 2012.

YAMAGUCHI, M.; SHARP, R. E. Complexity and coordination of root growth at low water potentials: recent advances from transcriptomic and proteomic analyses. Plant, Cell \& Environment, v. 33, n. 4, p. 590-603, april. 2010.

YAMANE, K. et al. Bundle sheath chloroplasts of rice are more sensitive to drought stress than mesophyll chloroplasts. Journal of Plant Physiology, v. 160, n. 11, p. 1319-1327, jan. 2003.

YANCEY, P. H. et al. Living with water stress: evolution of osmolyte systems. Science (New York, N.Y.), v. 217, n. 4566, p. 1214-1222, 24 sept. 1982.

YOSHIDA, T.; MOGAMI, J.; YAMAGUCHI-SHINOZAKI, K. ABA-dependent and ABA-independent signaling in response to osmotic stress in plants. Current Opinion in Plant Biology, v. 21, p. 133-139, oct. 2014.

YOU, J.; CHAN, Z. ROS Regulation During Abiotic Stress Responses in Crop Plants. Frontiers in Plant Science, v. 6,8 dec. 2015 .

ZHENG, J. et al. Genome-wide transcriptome analysis of two maize inbred lines under drought stress. Plant Molecular Biology, v. 72, n. 4-5, p. 407-421, mar. 2010. 


\title{
3. CHAPTER I - CHANGES IN THE SUGARCANE TRANSCRIPTOME IN RESPONSE OF DROUGTH AND RE-WATERING CONDITIONS
}

\begin{abstract}
In Brazil, sugarcane has an increasing economical importance represented by its role in the sugar and biofuel markets, and, therefore, there is an increasing need to use land with unfavorable conditions to expand the plantations. In this context, understanding the changes in sugarcane transcriptome that are interconnected with alterations in plant physiology provide usefull information to direct plant breeding works. This chapter aims to provide such integrated view by using the correlations between a variety of physiological parameters and the alteration of the expression of genes involved with the plant's response to water stress. In order to do that it was performed a greenhouse experiment using sugarcane plants from the variety SP80-3280, stressed for 4 days and 6 days, and also after two days of recovery. Physiological parameters evaluated included phostosynthesis, transpiration, stomatal conductance, water use efficiency, effective quantum yield, among others. Transcriptome analysis was done using microarray for all three conditions and RNA-Seq for the most discrepant condition (6 days without water). Results show that after 6 days without water there was a huge drop on the values for physiological parameters. Photosynthesis, for instance, decreased 98\%. Those alterations were reflected on the gene expression, once genes involved with photosynthetical processes were enriched in the down-regulated group of differentially expressed transcripts for stressed leaves. In the case of roots, there was also an enrichmed of genes involved with Cell Wall and Cell Wall Organization and Biogenesis in down-regulated transcripts and might be a reflection of the repression of root growth in greenhouse plants submitted to drought stress. The down-regulation of genes involved with Cell Wall Organization and Biogenesis was also observed in the RNA-Seq results. In general RNASeq allowed the identification of more than 28,000 differentially expressed features in leaves and more than 7,000 in roots, with classes only up-regulated and others only down-regulated. The orthologous group classification of identified sequences indicated the importance of Signal Transduction Mechanisms and Posttranslational modification, protein turnover, chaperones in leaves and Carbohydrate Transport and Metabolism and Signal Transduction Mechanisms in roots. The precursors of several micro RNAs involved with drought responses were also identified among the differentially expressed features from RNA-Seq. The study of KEGG pathways shed light on some pathways differential expression in leaves and roots, such as Phenylpropanoid Biosynthesis, Galactose Metabolism, Lipid Metabolism and Plant Hormone Signal Transduction. The last one indicated a major role for $\mathrm{ABA}$ independtly of the plant tissue and an interplay of several hormones in the leaves responses to water stress. The results of this chapter helped in the understanding of differences on the response to a major abiotic stress in distinct parts of sugarcane plants and also how these changes in the molecular level along with the transduction of the signals between the different parts of sugarcane organism have consequences to the whole plant physiological response.
\end{abstract}

Keywords: Sugarcane; Drought; Re-watering; Physiology; Transcriptome 


\subsection{Introduction}

Brazil is considered the world's largest producer of sugarcane, whose economical importance goes beyond the production of sugar and biofuels. Lately the perception that sugarcane can be used for a variety of processes, like bioprocessing for the production of chemicals such as polymers and new molecules has made the interest on study this amazing plant even bigger (SOUZA; FILHO, 2016). In this context, the promising role of sugarcane as a bioenergy crop makes the expansion of plantations to areas of severe drought common (GENTILE et al., 2015).

All the way through a plant's life cycle, they are submitted to different kinds of environmental stresses, that include water deficit, temperature extremes, salinity (HAYAT et al., 2012), among the abiotic, and pathogen infections among the biotic stresses. Drought is considered one of the major constraints for plant productivity worldwide (HAYANO-KANASHIRO et al., 2009)). In the countryside of São Paulo, for instance, the lack of rain caused a 15\% loss in sugarcane fields (PALHARES, 2014), which was reflected on the producer profit, causing finantial losses.

Drought is a complex trait and in order to understand its underlying mechanisms it is necessary to have a global view (WANG et al., 2016a), once the changes in expression of transcription factors, enzymes and other proteins must be translated to the alterations in plant morphology and physiology aiming the survival of the organism.

Root development, photosynthetic mechanisms, transpiration, stomatal control of $\mathrm{CO}_{2}$ diffusion, phostsynthetic efficiency (SAIBO; LOURENÇO; OLIVEIRA, 2009) are among the physiological parameters altered after water privation.

The investigation of changes in plant transcriptomes in response to environmental stresses is of fundamental importance for the selection of candidate genes for plant breeding programs. The use of large scale transcriptomic techniques to understand and characterize molecular changes due to water stress has been widespread in different plant species, stress conditions (from severe stress to re-watering) and using plants with different characteristics of drought tolerance or susceptibility (HAYANO-KANASHIRO et al., 2009; LU et al., 2017; ZHAO et al., 2016; ZHOU et al., 2014). The study of genes associated with drought avoidance or tolerance traits, for example, was performed in C4 hybrid bermudagrass plants (ZHOU et al., 2014) and found genes associated to dehydrationprotective proteins, stress signaling, oxidant stress defense. The study of rehydration is also interesting once tolerant genotypes seems to activate mechanisms that will lead to a more efficient recovery process (HAYANO-KANASHIRO et al., 2009).

The analysis of the whole organism's reactions to an environment stimulus is essential for the comprehension of the role that differentially expressed genes have in the plant's response to the environmental stresses. Most studies focus either on physiological and morphological changes caused due to drought or on the molecular aspects represented by data obtained from transcriptomic, proteomic, metabolomics works. Only a few, such as Hayano-Kanashiro et al., (2009) presents a correlation between both aspects.

Therefore, this part of the work aimed at analyzing sugarcane's response to drought stress not only in the molecular, but also in the physiological level, once the last one represents the phenotypical changes that parallel the molecular ones. An integrated and interconnected view of alterations in sugarcane due to water stress is provided in this chapter. 


\section{REFERENCES}

ANDERS, S.; PYL, P. T.; HUBER, W. HTSeq—a Python framework to work with high-throughput sequencing data.

Bioinformatics, v. 31, n. 2, p. 166-169, jan. 2015.

ANDRADE, J. C. F. DE et al. Expression profiles of sugarcane under drought conditions: Variation in gene regulation.

Genetics and Molecular Biology, v. 38, n. 4, p. 465-469, dec. 2015.

BENJAMINI, Y.; YEKUTIELI, D. The Control of the False Discovery Rate in Multiple Testing under Dependency. The Annals of Statistics, v. 29, n. 4, p. 1165-1188, 2001.

BLANCH, J.-S. et al. Drought, warming and soil fertilization effects on leaf volatile terpene concentrations in Pinus halepensis and Quercus ilex. Acta Physiologiae Plantarum, v. 31, n. 1, p. 207, oct. 2008.

BOLGER, A. M.; LOHSE, M.; USADEL, B. Trimmomatic: a flexible trimmer for Illumina sequence data. Bioinformatics, v. 30, n. 15, p. 2114-2120, aug. 2014.

CARDOSO-SILVA, C. B. et al. De Novo Assembly and Transcriptome Analysis of Contrasting Sugarcane Varieties. PLoS ONE, v. 9, n. 2, p. e88462, fev. 2014.

CASTRO, P. R. C. et al. AÇÃO COMPARADA DE ETHREL, FUZILADE E ROUNDUP, EM DUAS ÉPOCAS DE APLICAÇÃO, NA MATURAÇÃO E PRODUTIVIDADE DA CANA-DE-AÇÚCAR SP 70-1143. BRAZILIAN JOURNAL OF AGRICULTURE - Revista de Agricultura, v. 77, n. 1, p. 23-38, nov. 2015.

CHAUMONT, F.; TYERMAN, S. D. Aquaporins: Highly Regulated Channels Controlling Plant Water Relations. PLANT PHYSIOLOGY, v. 164, n. 4, p. 1600-1618, apr. 2014.

CHENG, M.-C. et al. The Arabidopsis ETHYLENE RESPONSE FACTOR1 Regulates Abiotic Stress-Responsive Gene Expression by Binding to Different cis-Acting Elements in Response to Different Stress Signals. PLANT PHYSIOLOGY, v. 162, n. 3, p. 1566-1582, jul. 2013.

CHEONG, Y. H. et al. CBL1, a calcium sensor that differentially regulates salt, drought, and cold responses in Arabidopsis. The Plant Cell, v. 15, n. 8, p. 1833-1845, aug. 2003.

COHEN, D. et al. Comparative transcriptomics of drought responses in Populus: a meta-analysis of genome-wide expression profiling in mature leaves and root apices across two genotypes. BMC genomics, v. 11, p. 630, nov. 2010.

CRUZ DE CARVALHO, M. H. Drought stress and reactive oxygen species. Plant Signaling \& Behavior, v. 3, n. 3, p. 156-165, mar. 2008.

DA SILVA, P. P. et al. Path analysis for selection of drought tolerant sugarcane genotypes through physiological components. Industrial Crops and Products, v. 37, n. 1, p. 11-19, may 2012.

DONG, C.-H. et al. Gene expression profiling of Sinapis alba leaves under drought stress and rewatering growth conditions with Illumina deep sequencing. Molecular Biology Reports, v. 39, n. 5, p. 5851-5857, may 2012.

ENDRES, L. Photosynthesis and Water Relations in Brazilian Sugarcane. The Open Agriculture Journal, v. 4, n. 1, p. 31-37, oct. 2010.

FAROOQ, M. et al. Physiological Role of Exogenously Applied Glycinebetaine to Improve Drought Tolerance in Fine Grain Aromatic Rice ( Oryza sativa L.). Journal of Agronomy and Crop Science, v. 194, n. 5, p. 325-333, oct. 2008 .

FAROOQ, M. et al. Improving the Drought Tolerance in Rice (Oryza sativa L.) by Exogenous Application of Salicylic Acid. Journal of Agronomy and Crop Science, v. 195, n. 4, p. 237-246, aug. 2009. 
FAROOQ, M. et al. Drought Stress in Plants: An Overview. In: AROCA, R. (Ed.). . Plant Responses to Drought Stress. Berlin, Heidelberg: Springer Berlin Heidelberg, 2012. p. 1-33.

FERREIRA, T. H. S. et al. Sugarcane Water Stress Tolerance Mechanisms and Its Implications on Developing Biotechnology Solutions. Frontiers in Plant Science, v. 8, jun. 2017.

FLEMING, Y. et al. Synergistic activation of stress-activated protein kinase 1/c-Jun N-terminal kinase (SAPK1/JNK) isoforms by mitogen-activated protein kinase kinase 4 (MKK4) and MKK7. Biochemical Journal, v. 352, n. Pt 1, p. 145-154, nov. 2000.

FRACASSO, A.; TRINDADE, L. M.; AMADUCCI, S. Drought stress tolerance strategies revealed by RNA-Seq in two sorghum genotypes with contrasting WUE. BMC Plant Biology, v. 16, n. 1, dec. 2016.

FUJII, H. et al. A miRNA Involved in Phosphate-Starvation Response in Arabidopsis. Current Biology, v. 15, n. 22, p. 2038-2043, nov. 2005.

FUJITA, Y. et al. ABA-mediated transcriptional regulation in response to osmotic stress in plants. Journal of Plant Research, v. 124, n. 4, p. 509-525, jul. 2011.

FUKUSHIMA, R. S.; KERLEY, M. S. Use of Lignin Extracted from Different Plant Sources as Standards in the Spectrophotometric Acetyl Bromide Lignin Method. Journal of Agricultural and Food Chemistry, v. 59, n. 8, p. 3505-3509, april. 2011.

GAO, F. et al. Identification of drought-responsive microRNAs and their targets in Ammopiptanthus mongolicus by using high-throughput sequencing. Scientific Reports, v. 6, n. 1, dec. 2016.

GARG, A. K. et al. Trehalose accumulation in rice plants confers high tolerance levels to different abiotic stresses. Proceedings of the National Academy of Sciences, v. 99, n. 25, p. 15898-15903, dec. 2002.

GARG, R. et al. Transcriptome analyses reveal genotype- and developmental stage-specific molecular responses to drought and salinity stresses in chickpea. Scientific Reports, v. 6, n. 1, may 2016.

GARG, R.; VARSHNEY, R. K.; JAIN, M. Molecular genetics and genomics of abiotic stress responses. Frontiers in Plant Science, v. 5, aug. 2014.

GENTILE, A. et al. MicroRNAs and drought responses in sugarcane. Frontiers in Plant Science, v. 6, 23 fev. 2015.

GOLLDACK, D. et al. Tolerance to drought and salt stress in plants: Unraveling the signaling networks. Frontiers in Plant Science, v. 5, april. 2014.

GRABHERR, M. G. et al. Full-length transcriptome assembly from RNA-Seq data without a reference genome. Nature Biotechnology, v. 29, n. 7, p. 644-652, may 2011.

GUEGUEN, V. et al. Fatty acid and lipoic acid biosynthesis in higher plant mitochondria. The Journal of Biological Chemistry, v. 275, n. 7, p. 5016-5025, feb. 2000.

GUO, W.-J.; DAVID HO, T.-H. An Abscisic Acid-Induced Protein, HVA22, Inhibits Gibberellin-Mediated Programmed Cell Death in Cereal Aleurone Cells. PLANT PHYSIOLOGY, v. 147, n. 4, p. 1710-1722, aug. 2008.

HAAS, B. J. et al. De novo transcript sequence reconstruction from RNA-seq using the Trinity platform for reference generation and analysis. Nature Protocols, v. 8, n. 8, p. 1494-1512, 11 jul. 2013.

HAMZA, N. B. et al. MicroRNA expression profiles in response to drought stress in Sorghum bicolor. Gene Expression Patterns, v. 20, n. 2, p. 88-98, mar. 2016.

HANIN, M. et al. Plant dehydrins and stress tolerance: versatile proteins for complex mechanisms. Plant Signaling \& Behavior, v. 6, n. 10, p. 1503-1509, oct. 2011. 
HAYANO-KANASHIRO, C. et al. Analysis of Gene Expression and Physiological Responses in Three Mexican Maize Landraces under Drought Stress and Recovery Irrigation. PLoS ONE, v. 4, n. 10, p. e7531, oct. 2009.

HAYAT, S. et al. Role of proline under changing environments: A review. Plant Signaling \& Behavior, v. 7, n. 11, p. 1456-1466, nov. 2012.

HU, Y. et al. Differential expression of candidate genes for lignin biosynthesis under drought stress in maize leaves. Journal of Applied Genetics, v. 50, n. 3, p. 213-223, sept. 2009.

HUANG, D.-L. et al. Transcriptome of High-Sucrose Sugarcane Variety GT35. Sugar Tech, v. 18, n. 5, p. 520-528, oct. 2016.

INGRAM, J.; BARTELS, D. THE MOLECULAR BASIS OF DEHYDRATION TOLERANCE IN PLANTS. Annual Review of Plant Physiology and Plant Molecular Biology, v. 47, n. 1, p. 377-403, jun. 1996.

ISKANDAR, H. M. et al. Comparison of reference genes for quantitative real-time polymerase chain reaction analysis of gene expression in sugarcane. Plant Molecular Biology Reporter, v. 22, n. 4, p. 325-337, dec. 2004.

JAVOT, H.; MAUREL, C. The role of aquaporins in root water uptake. Annals of Botany, v. 90, n. 3, p. 301-313, sept. 2002.

JOHANSSON, I. et al. The role of aquaporins in cellular and whole plant water balance. Biochimica et Biophysica Acta (BBA) - Biomembranes, v. 1465, n. 1-2, p. 324-342, may 2000.

JOSHI, R. et al. Transcription Factors and Plants Response to Drought Stress: Current Understanding and Future Directions. Frontiers in Plant Science, v. 7, jul. 2016.

KAKUMANU, A. et al. Effects of Drought on Gene Expression in Maize Reproductive and Leaf Meristem Tissue Revealed by RNA-Seq. PLANT PHYSIOLOGY, v. 160, n. 2, p. 846-867, oct. 2012.

KANEHISA, M. et al. KEGG as a reference resource for gene and protein annotation. Nucleic Acids Research, v. 44, n. D1, p. D457-462, jan. 2016.

KERR, K. F. Extended analysis of benchmark datasets for Agilent two-color microarrays. BMC Bioinformatics, v. 8, n. 1, p. 371, 2007.

KIANI, S. P. et al. Genetic analysis of plant water status and osmotic adjustment in recombinant inbred lines of sunflower under two water treatments. Plant Science, v. 172, n. 4, p. 773-787, april. 2007.

KIDO, É. A. et al. New Insights in the Sugarcane Transcriptome Responding to Drought Stress as Revealed by Supersage. The Scientific World Journal, v. 2012, p. 1-14, 2012.

KIM, J.; MALLADI, A.; VAN IERSEL, M. W. Physiological and molecular responses to drought in Petunia: the importance of stress severity. Journal of Experimental Botany, v. 63, n. 18, p. 6335-6345, nov. 2012.

KOGENARU, S. et al. RNA-seq and microarray complement each other in transcriptome profiling. BMC Genomics, v. 13, n. 1, p. 629, 2012.

KOHLI, A. et al. Root proteases: reinforced links between nitrogen uptake and mobilization and drought tolerance. Physiologia Plantarum, v. 145, n. 1, p. 165-179, may 2012.

KOIWA, H. et al. The STT3a Subunit Isoform of the Arabidopsis Oligosaccharyltransferase Controls Adaptive Responses to Salt/Osmotic Stress. The Plant Cell Online, v. 15, n. 10, p. 2273-2284, oct. 2003.

KOSOVÁ, K.; VITÁMVÁS, P.; PRÁŠIL, I. T. Wheat and barley dehydrins under cold, drought, and salinity â€“ what can LEA-II proteins tell us about plant stress response? Frontiers in Plant Science, v. 5, 9 jul. 2014.

KOTTAPALLI, K. R.; SARLA, N.; KIKUCHI, S. In silico insight into two rice chromosomal regions associated with submergence tolerance and resistance to bacterial leaf blight and gall midge. Biotechnology Advances, v. 24, n. 6, p. 561-589, dec. 2006. 
KÜLTZ, D. Evolution of Osmosensory MAP Kinase Signaling Pathways. American Zoologist, v. 41, n. 4, p. 743757, 2001.

KUMAR, D. et al. Transcriptome analysis of Arabidopsis mutants suggests a crosstalk between ABA, ethylene and GSH against combined cold and osmotic stress. Scientific Reports, v. 6, n. 1, dec. 2016.

LANGMEAD, B.; SALZBERG, S. L. Fast gapped-read alignment with Bowtie 2. Nature Methods, v. 9, n. 4, p. 357359, mar. 2012.

LEMBKE, C. G. et al. Identification of sense and antisense transcripts regulated by drought in sugarcane. Plant Molecular Biology, v. 79, n. 4-5, p. 461-477, jul. 2012.

LENKA, S. K. et al. Comparative analysis of drought-responsive transcriptome in Indica rice genotypes with contrasting drought tolerance: Drought-responsive transcriptome analysis in rice. Plant Biotechnology Journal, v. 9, n. 3, p. 315-327, april. 2011.

LEONHARDT, N. Microarray Expression Analyses of Arabidopsis Guard Cells and Isolation of a Recessive Abscisic Acid Hypersensitive Protein Phosphatase 2C Mutant. THE PLANT CELL ONLINE, v. 16, n. 3, p. 596-615, mar. 2004.

LI, B.; DEWEY, C. N. RSEM: accurate transcript quantification from RNA-Seq data with or without a reference genome. BMC Bioinformatics, v. 12, n. 1, p. 323, 2011.

LI, C. et al. Differential expression profiles and pathways of genes in sugarcane leaf at elongation stage in response to drought stress. Scientific Reports, v. 6, n. 1, sept. 2016a.

LI, M. et al. De novo analysis of transcriptome reveals genes associated with leaf abscission in sugarcane (Saccharum officinarum L.). BMC Genomics, v. 17, n. 1, dec. 2016b.

LI, W.-X. et al. The Arabidopsis NFYA5 Transcription Factor Is Regulated Transcriptionally and Posttranscriptionally to Promote Drought Resistance. THE PLANT CELL ONLINE, v. 20, n. 8, p. 2238-2251, aug. 2008.

LI, Y. C. et al. Comparative analysis of water stress-responsive transcriptomes in drought-susceptible and -tolerant wheat (Triticum aestivum L.). Journal of Plant Biology, v. 55, n. 5, p. 349-360, oct. 2012.

LIM, L. P. The microRNAs of Caenorhabditis elegans. Genes \& Development, v. 17, n. 8, p. 991-1008, 15 april. 2003.

LIU, H.-H. et al. Microarray-based analysis of stress-regulated microRNAs in Arabidopsis thaliana. RNA, v. 14, n. 5, p. 836-843, mar. 2008.

LIU, M. et al. Profiling of drought-responsive microRNA and mRNA in tomato using high-throughput sequencing. BMC Genomics, v. 18, n. 1, dec. 2017.

LOVE, M. I.; HUBER, W.; ANDERS, S. Moderated estimation of fold change and dispersion for RNA-seq data with DESeq2. Genome Biology, v. 15, n. 12, p. 550, 2014.

LU, X. et al. RNA-seq Analysis of Cold and Drought Responsive Transcriptomes of Zea mays ssp. mexicana L. Frontiers in Plant Science, v. 8, 7 feb. 2017.

LUO, W. et al. Pathview Web: user friendly pathway visualization and data integration. Nucleic Acids Research, may 2017.

MA, Y. et al. Regulators of PP2C phosphatase activity function as abscisic acid sensors. Science (New York, N.Y.), v. 324, n. 5930, p. 1064-1068, may 2009.

MANSOURI, H.; ASRAR, Z.; MEHRABANI, M. Effects of gibberellic acid on primary terpenoids and deltatetrahydrocannabinol in Cannabis sativa at flowering stage. Journal of Integrative Plant Biology, v. 51, n. 6, p. 553-561, jun. 2009. 
MAXWELL, K.; JOHNSON, G. N. Chlorophyll fluorescence--a practical guide. Journal of Experimental Botany, v. 51, n. 345, p. 659-668, april. 2000.

MEDEIROS, D. B. et al. Physiological limitations in two sugarcane varieties under water suppression and after recovering. Theoretical and Experimental Plant Physiology, v. 25, n. 3, p. 213-222, 2013.

MIRZAEI, M. et al. Differential regulation of aquaporins, small GTPases and V-ATPases proteins in rice leaves subjected to drought stress and recovery. PROTEOMICS, v. 12, n. 6, p. 864-877, mar. 2012.

MORISON, J. I. . et al. Improving water use in crop production. Philosophical Transactions of the Royal Society B: Biological Sciences, v. 363, n. 1491, p. 639-658, 12 feb. 2008.

MORIYA, Y. et al. KAAS: an automatic genome annotation and pathway reconstruction server. Nucleic Acids Research, v. 35, n. Web Server issue, p. W182-185, jul. 2007.

MOUMENI, A. et al. Comparative analysis of root transcriptome profiles of two pairs of drought-tolerant and susceptible rice near-isogenic lines under different drought stress. BMC Plant Biology, v. 11, n. 1, p. $174,2011$.

MOURA, J. C. M. S. et al. Abiotic and Biotic Stresses and Changes in the Lignin Content and Composition in Plants. Journal of Integrative Plant Biology, v. 52, n. 4, p. 360-376, april. 2010.

MURATA, M. et al. Molecular strategy for survival at a critical high temperature in Eschierichia coli. PloS One, v. 6, n. 6, p. e20063, 2011.

NAKASHIMA, K.; YAMAGUCHI-SHINOZAKI, K.; SHINOZAKI, K. The transcriptional regulatory network in the drought response and its crosstalk in abiotic stress responses including drought, cold, and heat. Frontiers in Plant Science, v. 5, may 2014.

NISHIYAMA, M. Y. et al. Full-Length Enriched cDNA Libraries and ORFeome Analysis of Sugarcane Hybrid and Ancestor Genotypes. PLoS ONE, v. 9, n. 9, p. e107351, 15 sept. 2014.

NISHIZAWA, A.; YABUTA, Y.; SHIGEOKA, S. Galactinol and raffinose constitute a novel function to protect plants from oxidative damage. Plant Physiology, v. 147, n. 3, p. 1251-1263, jul. 2008.

NOCTOR, G.; MHAMDI, A.; FOYER, C. H. The Roles of Reactive Oxygen Metabolism in Drought: Not So Cut and Dried. PLANT PHYSIOLOGY, v. 164, n. 4, p. 1636-1648, 1 april. 2014.

OKAZAKI, Y.; SAITO, K. Roles of lipids as signaling molecules and mitigators during stress response in plants. The Plant Journal, v. 79, n. 4, p. 584-596, 1 aug. 2014.

PACKER, L.; WITT, E. H.; TRITSCHLER, H. J. alpha-Lipoic acid as a biological antioxidant. Free Radical Biology \& Medicine, v. 19, n. 2, p. 227-250, aug. 1995.

PAPINI-TERZI, F. S. et al. Sugarcane genes associated with sucrose content. BMC Genomics, v. 10, n. 1, p. 120, 2009.

PAYTON, P. et al. Examining the drought stress transcriptome in cotton leaf and root tissue. Biotechnology Letters, v. 33, n. 4, p. 821-828, april. 2011.

PFAFFL, M. W.; HORGAN, G. W.; DEMPFLE, L. Relative expression software tool (RESTC) for group-wise comparison and statistical analysis of relative expression results in real-time PCR. Nucleic Acids Research, v. 30, n. 9, p. e36, may 2002.

PIAO, H. et al. OsCIPK31, a CBL-interacting protein kinase is involved in germination and seedling growth under abiotic stress conditions in rice plants. Molecules and Cells, v. 30, n. 1, p. 19-27, jul. 2010.

PINHEIRO, C.; CHAVES, M. M. Photosynthesis and drought: can we make metabolic connections from available data? Journal of Experimental Botany, v. 62, n. 3, p. 869-882, jan. 2011. 
POSPÍŠILOVÁ, J.; SYNKOVÁ, H.; RULCOVÁ, J. Cytokinins and Water Stress. Biologia Plantarum, v. 43, n. 3, p. 321-328, 1 sept. 2000.

PRABU, G. et al. Identification of Water Deficit Stress Upregulated Genes in Sugarcane. Plant Molecular Biology Reporter, v. 29, n. 2, p. 291-304, jun. 2011.

QUE, Y. et al. A Global View of Transcriptome Dynamics during Sporisorium scitamineum Challenge in Sugarcane by RNA-seq. PLoS ONE, v. 9, n. 8, p. e106476, 29 aug. 2014.

RAMACHANDRA REDDY, A.; CHAITANYA, K. V.; VIVEKANANDAN, M. Drought-induced responses of photosynthesis and antioxidant metabolism in higher plants. Journal of Plant Physiology, v. 161, n. 11, p. 11891202, nov. 2004.

RAMESH, P. Sugarcane Breeding Institute, Coimbatore, India Effect of Different Levels of Drought during the Formative Phase on Growth Parameters and its Relationship with Dry Matter Accumulation in Sugarcane. Journal of Agronomy and Crop Science, v. 185, n. 2, p. 83-89, sept. 2000.

RÉBEILLÉ, F. et al. Folates in plants: biosynthesis, distribution, and enhancement. Physiologia Plantarum, v. 126, n. 3, p. 330-342, 1 mar. 2006.

REZA SEPASKHAH, A.; AHMADI, S. H. A review on partial root-zone drying irrigation. [s.l: s.n.]. v. 4

RIBEIRO, M. S. et al. Partial rootzone drying in sugarcane (Saccharum officinarum L.): effects on gas exchange, growth and water use efficiency. Theoretical and Experimental Plant Physiology, v. 26, n. 3-4, p. 251-262, 1 dec. 2014.

ROCHA, F. R. et al. Signal transduction-related responses to phytohormones and environmental challenges in sugarcane. BMC Genomics, v. 8, n. 1, p. 71, 2007.

RODRIGUES, F. A. et al. Sugarcane genes differentially expressed during water deficit. Biologia Plantarum, v. 55, n. 1, p. 43-53, 1 mar. 2011.

RODRIGUES, F. A.; DE LAIA, M. L.; ZINGARETTI, S. M. Analysis of gene expression profiles under water stress in tolerant and sensitive sugarcane plants. Plant Science, v. 176, n. 2, p. 286-302, 1 feb. 2009.

RODRIGUEZ, M.; CANALES, E.; BORRAS-HIDALGO, O. Molecular aspects of abiotic stress in plants. [s.l: s.n.]. v. 22

SAEZ, A. et al. Enhancement of abscisic acid sensitivity and reduction of water consumption in Arabidopsis by combined inactivation of the protein phosphatases type 2C ABI1 and HAB1. Plant Physiology, v. 141, n. 4, p. 1389-1399, aug. 2006.

SAIBO, N. J. M.; LOURENÇO, T.; OLIVEIRA, M. M. Transcription factors and regulation of photosynthetic and related metabolism under environmental stresses. Annals of Botany, v. 103, n. 4, p. 609-623, feb. 2009.

SANTOS, T. B. D. et al. Galactinol synthase transcriptional profile in two genotypes of Coffea canephora with contrasting tolerance to drought. Genetics and Molecular Biology, v. 38, n. 2, p. 182-190, may 2015.

SEN, C. K.; ROY, S.; PACKER, L. Involvement of intracellular Ca2+ in oxidant-induced NF-kappa B activation. FEBS letters, v. 385, n. 1-2, p. 58-62, 29 april. 1996.

SHEN, Q. et al. The stress- and abscisic acid-induced barley gene HVA22: developmental regulation and homologues in diverse organisms. Plant Molecular Biology, v. 45, n. 3, p. 327-340, feb. 2001.

SHINOZAKI, K.; YAMAGUCHI-SHINOZAKI, K. Gene Expression and Signal Transduction in Water-Stress Response. Plant Physiology, v. 115, n. 2, p. 327-334, oct. 1997. 
SHINOZAKI, K.; YAMAGUCHI-SHINOZAKI, K. Molecular responses to dehydration and low temperature: differences and cross-talk between two stress signaling pathways. Current Opinion in Plant Biology, v. 3, n. 3 , p. 217-223, 2000.

SHINOZAKI, K.; YAMAGUCHI-SHINOZAKI, K. Gene networks involved in drought stress response and tolerance. Journal of Experimental Botany, v. 58, n. 2, p. 221-227, 6 nov. 2006.

SILVA, M. DE A. et al. Use of physiological parameters as fast tools to screen for drought tolerance in sugarcane. Brazilian Journal of Plant Physiology, v. 19, n. 3, p. 193-201, sept. 2007.

SILVA, M. DE A. et al. Photosynthetic capacity and water use efficiency in sugarcane genotypes subject to water deficit during early growth phase. Brazilian Archives of Biology and Technology, v. 56, n. 5, p. 735-748, oct. 2013b.

SINGH, D.; LAXMI, A. Transcriptional regulation of drought response: a tortuous network of transcriptional factors. Frontiers in Plant Science, v. 6, 29 oct. 2015.

SOKOL, A. et al. Up-regulation of stress-inducible genes in tobacco and Arabidopsis cells in response to abiotic stresses and ABA treatment correlates with dynamic changes in histone H3 and H4 modifications. Planta, v. 227, n. 1, p. 245-254, 15 nov. 2007.

SORIN, C. et al. A miR169 isoform regulates specific NF-YA targets and root architecture in Arabidopsis. New Phytologist, v. 202, n. 4, p. 1197-1211, jun. 2014.

SOUZA, G. M.; FILHO, R. M. Industrial Biotechnology and Biomass: What Next for Brazil's Future Energy and Chemicals? Industrial Biotechnology, v. 12, n. 1, p. 24-25, feb. 2016.

STEUDLE, E.; PETERSON, C. A. How does water get through roots? Journal of Experimental Botany, v. 49, n. 322, p. 775-788, 1 may 1998.

STOOF, C. R.; WESSELING, J. G.; RITSEMA, C. J. Effects of fire and ash on soil water retention. Geoderma, v. 159, n. 3, p. 276-285, 15 nov. 2010.

SUGIHARTO, B. et al. Identification and characterization of a gene encoding drought-inducible protein localizing in the bundle sheath cell of sugarcane. Plant \& Cell Physiology, v. 43, n. 3, p. 350-354, mar. 2002.

TAIZ, L. Fisiologia vegetal. Porto Alegre: Artmed, 2010.

TAUSZ, M. et al. Short-term changes in free radical scavengers and chloroplast pigments in Pinus canariensis needles as affected by mild drought stress. Journal of Plant Physiology, v. 158, n. 2, p. 213-219, jan. 2001.

TURTOLA, S. et al. Drought stress alters the concentration of wood terpenoids in Scots pine and Norway spruce seedlings. Journal of chemical ecology, 2003.

SUGARCANE INDUSTRY UNION $\quad-\quad$ ÚNICA. Available at: $<\mathrm{http}: / /$ www.unica.com.br/content/show.asp?cntCode $=\{$ D6C39D36-69BA-458D-A95C-815C87E4404D $\}>$. Access at: 03 jul. 2014.

VANDESOMPELE, J. et al. Accurate normalization of real-time quantitative RT-PCR data by geometric averaging of multiple internal control genes. Genome Biology, v. 3, n. 7, p. research0034.1-research0034.11, 2002.

VERBRUGGEN, N.; HERMANS, C. Proline accumulation in plants: a review. Amino Acids, v. 35, n. 4, p. 753-759, nov. 2008.

VERSLUES, P. E.; SHARMA, S. Proline Metabolism and Its Implications for Plant-Environment Interaction. The Arabidopsis Book, v. 8, p. e0140, jan. 2010.

VICENTINI, R. et al. Large-Scale Transcriptome Analysis of Two Sugarcane Genotypes Contrasting for Lignin Content. PLOS ONE, v. 10, n. 8, p. e0134909, 4 aug. 2015. 
VÊNCIO, R. Z. N.; KOIDE, T. HTself: Self-Self Based Statistical Test for Low Replication Microarray Studies. DNA Research, v. 12, n. 3, p. 211-214, 1 jan. 2005.

WANG, X. et al. Drought-Responsive Mechanisms in Plant Leaves Revealed by Proteomics. International Journal of Molecular Sciences, v. 17, n. 10, p. 1706, 18 oct. 2016a.

WILLIAMS, L.; ARAUJO, F. J. Correlations among predawn leaf, midday leaf, and midday stem water potential and their correlations with other measures of soil and plant water status in Vitis vinifera. [s.l: s.n.]. v. 127

XUE, L.-J.; ZHANG, J.-J.; XUE, H.-W. Characterization and expression profiles of miRNAs in rice seeds. Nucleic Acids Research, v. 37, n. 3, p. 916-930, feb. 2009.

YAMANE, K. et al. Bundle sheath chloroplasts of rice are more sensitive to drought stress than mesophyll chloroplasts. Journal of Plant Physiology, v. 160, n. 11, p. 1319-1327, jan. 2003.

YANG, Y. H. et al. Normalization for cDNA microarray data: a robust composite method addressing single and multiple slide systematic variation. Nucleic Acids Research, v. 30, n. 4, p. e15, 15 feb. 2002.

YOU, J.; CHAN, Z. ROS Regulation During Abiotic Stress Responses in Crop Plants. Frontiers in Plant Science, v. 6, 8 dec. 2015.

YUAN, L. et al. Involvement of Histone Modifications in Plant Abiotic Stress Responses: Histone Modifications in Plant Abiotic Stress Responses. Journal of Integrative Plant Biology, p. n/a-n/a, jun. 2013.

ZENG, Y.; YANG, T. RNA isolation from highly viscous samples rich in polyphenols and polysaccharides. Plant Molecular Biology Reporter, v. 20, n. 4, p. 417-417, 1 dec. 2002.

ZHANG, J. et al. Molecular character of a phosphatase 2C (PP2C) gene relation to stress tolerance in Arabidopsis thaliana. Molecular Biology Reports, v. 40, n. 3, p. 2633-2644, mar. 2013.

ZHANG, J. et al. Identification of microRNAs in Response to Drought in Common Wild Rice (Oryza rufipogon Griff.) Shoots and Roots. PLOS ONE, v. 12, n. 1, p. e0170330, 20 jan. 2017.

ZHAO, P. et al. New Insights on Drought Stress Response by Global Investigation of Gene Expression Changes in Sheepgrass (Leymus chinensis). Frontiers in Plant Science, v. 7, 30 jun. 2016.

ZHENG, J. et al. Genome-wide transcriptome analysis of two maize inbred lines under drought stress. Plant Molecular Biology, v. 72, n. 4-5, p. 407-421, mar. 2010.

ZHOU, P. et al. Characterization of Gene Expression Associated with Drought Avoidance and Tolerance Traits in a Perennial Grass Species. PLoS ONE, v. 9, n. 8, p. e103611, 25 aug. 2014.

ZHU, Y.; DONG, A.; SHEN, W.-H. Histone variants and chromatin assembly in plant abiotic stress responses. Biochimica et Biophysica Acta (BBA) - Gene Regulatory Mechanisms, v. 1819, n. 3-4, p. 343-348, mar. 2012. 


\title{
4. CHAPTER II - CO-EXPRESSION ANALYSIS OF SUGARCANE DROUGHT EXPERIMENTS
}

\begin{abstract}
Gene networks are considered the basis of biological complexity and have become the core area of research in systems biology. Their analysis help in the identification of patterns of responses related to specific conditions as well as hypothesize about the function of unknown genes, once transcriptionally co-expressed genes tend to be functionally related. Moreover, the possibility of relating the co-expressed genes with physiological responses or to hormone crosstalk may help us getting insight into the genes coordinated action that culminate in a specific response. This chapter aimed to obtain a co-expression network of genes involved in drought by relating them with (a) physiological parameters considered important for water stress responses; (b) analyzing the co-expression modules in which players of the signal transduction pathway of $\mathrm{ABA}$, auxin and ethylene belong to. These hormone related genes were also used for the study of the changes in gene expression during the progression of drought, with the goal of observing if their pattern of expression and their co-expression are similar. Coexpression analysis used data from two greenhouse and one field drought related experiments, in which materials from different sugarcane varieties and plant parts (leaves, roots and internodes) were used. The analysis of gene expression changes during drought was performed using leaves of water stressed sugarcane SP80-3280 plants, and the genes studied were chosen accordingly to data obtained from previous experiments. Co-expression results showed the existence of 43 modules with genes expressed in a similar way, from these, 3 were correlated with physiological parameters of interest, such as photosynthesis and transpiration, and 15 contained genes chosen for the evaluation of gene expression changes in the daily basis in response to drought. Dark Orange2, Dark Red and Maroon were the modules correlated with physiological parameters, and interestingly showed genes from the top nodes involved with the avoidance of damage in photosynthetical membranes, protection of macromolecules, antioxidant response, protein ubiquitination and transcription factor activity. In the case of the modules from genes studied in the drought progression experiments, most of the nodes belong to Function Unknown orthologous group category, Posttransational Modification, protein turnover, chaperones, Transcription and Signal Transduction Mechanisms, and highlighted the importance of some group of genes in sugarcane's response to water stress. Among those are calcium binding proteins, transcription factors and cryptochromes. The further analysis of the results are helping in the selection of interesting genes to be identified in the sugarcane genome and used in the future for biotechnological approaches. The study of drought progression showed that the expression of several genes start to decrease after the sixth day and may indicate the plant might be entering the senescence process, and also that the peak of expression for several genes known to have roles in drought responses happens between the forth and the sixth day.
\end{abstract}

Keywords: Sugarcane; Co-Expression; Greenhouse; Field; Drought 


\subsection{Introduction}

The molecular response of plants to abiotic stresses has been often considered as a complex process mainly based on the activation of some signaling pathways and the modulation of transcriptional activity of stress-related genes (COSTA et al., 2008; MAZZUCOTELLI et al., 2008). Some genes respond to water stress very rapidly, whereas others are induced slowly after the accumulation of ABA (SHINOZAKI; YAMAGUCHI-SHINOZAKI, 1997). Such genes are thought to function not only in protecting cells from water deficit by producing important metabolic proteins, but also in the regulation of genes for signal transduction in the water-stress response (SHINOZAKI; YAMAGUCHISHINOZAKI, 1997).

The identification of signaling and gene regulatory pathways in cells affected by different stresses, as well as the interaction between the pathways constitutes one of the major interests in the signal transduction pathway research area (COSTA et al., 2008; SEKI et al., 2003). These interactions define the temporal and spatial pattern of expression of a specific group of genes (MEJIA-GUERRA et al., 2012). The importance of these studies relies on the fact that gene expression is frequently the prime mover, in other words, the first step of a response (BLAIS, 2005). Therefore, the identification and comprehension of regulatory networks, as well as the way they are built and interact, are fundamental for the understanding of tolerance mechanisms and provide targets for genetic manipulation (MARCOLINO-GOMES et al., 2013; VAN DRIEL, 2003).

The modulation of expression of several genes help plants to cope with water stress and optimize their growth and development (SINGH; LAXMI, 2015). Abscisic Acid (ABA) is considered a master player on such responses. Plants responses to drought can be divided in two major pathways: ABA-dependent and ABA-independent pathways (SINGH; LAXMI, 2015). Other well known phytohoromes players involved in plants drought responses are ethylene, involved in senescence, and auxin, involved in stomatal movements.

Moreover, stress responses are not linear pathways, and involve changes at molecular, cellular and physiological levels, constituting integrated circuits that involve a plethora of pathways, cell compartments, tissues and the interaction of additional cofactors and signaling molecules (RODRIGUEZ; CANALES; BORRAS-HIDALGO, 2005).

Drought stress changes plant morphology leading to alterations on several physiological parameters that will ultimately promote photoinhibition and oxidative damage on the cells (PINHEIRO; CHAVES, 2011). In this aspect, understanding only the molecular responses characterized by sensing of the stress, transducing the signal and activating stress-responsive genes, along with the cellular mechanisms that will involve genes related to protection of macromolecules and membranes, detoxification enzymes, proteases and osmoprotectants (SHINOZAKI; YAMAGUCHI-SHINOZAKI, 1997), is not enough.

Such an intricate response demonstrates that studies focusing on only a specific aspect tend to be incomplete and to neglect important factors. Nowadays it is necessary not only to understand one or another characteristic of the response, but instead to integrate the physiology, gene regulation and cellular mechanisms and, therefore, obtain a comprehensive view of the plant responses.

In this part of the work it was aimed to obtain a drought co-expression network using the data from the drought experiment previously analyzed in this work, as well as using data formerly generated by the group, also related to the same environmental stress. Furthermore, it was aimed to analyze the relationship between genes related to the main hormones involved in water stress responses, $\mathrm{ABA}$, auxin and ethylene, on the co-expressed networks as well as 
to evaluate the relative expression of genes involved in ABA-dependent and ABA-independent pathways during the progression of the stress.

\subsection{Specific Objectives}

- Analyze the physiology and changes in gene expression of selected genes during the progression of drought in sugarcane.

- Compare microarray data obtained from this experiment with data obtained from previous experiments of the group and generate a sugarcane drought co-expression network;

- Identify genes that have a similar pattern of expression during drought progression and also belong to the same co-expression module;

- Identify interesting genes that may be targets for future studies.

\subsection{Material and Methods}

\subsubsection{Drought Progression Physiology and Gene Expression Analysis}

\subsubsection{Plant Material}

Sugarcane plants (Saccharum spp) cultivar SP80-3280 were grown in greenhouse under irrigated and drought conditions. Plants were seven-month-old and cultivated in 20 liters pots. The tissues collected were leaves L+3 for RNA extraction during the progression of the drought. One eye sett of sugarcane was planted in 20 liter pots containing a mixture of 2 parts soil: 2 parts substrate: 1 part vermiculite. Until the beginning of the drought treatments, the soil was kept near the field capacity (FC) in the same manner as the experiment in Alagoas Federal University. The soil water content was monitored by three measurements of soil humidity per pot, in a depth of $10 \mathrm{~cm}$ each day after stress treatments, using the soil moisture meter MO750 (EXTECH Instruments, Nashua - New Hampshire).

\subsubsection{Analysis of physiology parameters}

The physiology parameters evaluated were photosynthesis, stomatal conductance and transpiration. Measures were done with a LICOR LI-6400 Portable Photosynthesis System (LI-COR, Lincoln - Nebraska). All measures were performed between $9 \mathrm{~h}$ to $11 \mathrm{~h}$ am on leaves $\mathrm{L}+1$. A recovery time period of 24 hours (between day 7 and day 9) was given to the plants after they were watered again. Therefore, there are no physiology measures on day 8.

For physiological analysis, the t-test was used to determine statistical significant difference between irrigated, drought and rehydrated samples. Excel was used for the t-test and graphs were built using GraphPad Prism 5. 


\section{REFERENCES}

AMBAWAT, S. et al. MYB transcription factor genes as regulators for plant responses: an overview. Physiology and Molecular Biology of Plants, v. 19, n. 3, p. 307-321, jul. 2013.

AMIR HOSSAIN, M. et al. The bZIP transcription factor OsABF1 is an ABA responsive element binding factor that enhances abiotic stress signaling in rice. Plant Molecular Biology, v. 72, n. 4-5, p. 557-566, mar. 2010.

ANDRADE, J. C. F. DE et al. Expression profiles of sugarcane under drought conditions: Variation in gene regulation. Genetics and Molecular Biology, v. 38, n. 4, p. 465-469, dec. 2015.

ARAVIND, L.; KOONIN, E. V. G-patch: a new conserved domain in eukaryotic RNA-processing proteins and type D retroviral polyproteins. Trends in Biochemical Sciences, v. 24, n. 9, p. 342-344, sept. 1999.

BALDONI, E.; GENGA, A.; COMINELLI, E. Plant MYB Transcription Factors: Their Role in Drought Response Mechanisms. International Journal of Molecular Sciences, v. 16, n. 7, p. 15811-15851, jul. 2015.

BLAIS, A. Constructing transcriptional regulatory networks. Genes \& Development, v. 19, n. 13, p. 1499-1511, jul. 2005.

CAI, G. et al. A maize mitogen-activated protein kinase kinase, ZmMKK1, positively regulated the salt and drought tolerance in transgenic Arabidopsis. Journal of Plant Physiology, v. 171, n. 12, p. 1003-1016, jul. 2014.

CHEN, Y.-S. et al. A late embryogenesis abundant protein HVA1 regulated by an inducible promoter enhances root growth and abiotic stress tolerance in rice without yield penalty. Plant Biotechnology Journal, v. 13, n. 1, p. 105-116, jan. 2015.

CHENG, M.-C. et al. The Arabidopsis ETHYLENE RESPONSE FACTOR1 Regulates Abiotic Stress-Responsive Gene Expression by Binding to Different cis-Acting Elements in Response to Different Stress Signals. PLANT PHYSIOLOGY, v. 162, n. 3, p. 1566-1582, jul. 2013.

CHOI, H. et al. ABFs, a family of ABA-responsive element binding factors. The Journal of Biological Chemistry, v. 275 , n. 3, p. 1723-1730, jan. 2000.

COMINELLI, E. et al. A Guard-Cell-Specific MYB Transcription Factor Regulates Stomatal Movements and Plant Drought Tolerance. Current Biology, v. 15, n. 13, p. 1196-1200, jul. 2005.

COSTA, M. Estudo do transcriptoma associado ao déficit hídrico e desenvolvimento de imunoprecipitação de cromatina em cana de açúcar para estudos de redes regulatórias transcricionais.phD dissertation, , 2011.

COSTA, M. D. L. et al. A New Branch of Endoplasmic Reticulum Stress Signaling and the Osmotic Signal Converge on Plant-specific Asparagine-rich Proteins to Promote Cell Death. Journal of Biological Chemistry, v. 283, n. 29, p. 20209-20219, jul. 2008.

CUI, F. et al. Regulation of ABA dependent wound induced spreading cell death by MYB108. New Phytologist, v. 200, n. 3, p. 634-640, nov. 2013.

DA SILVA, P. P. et al. Path analysis for selection of drought tolerant sugarcane genotypes through physiological components. Industrial Crops and Products, v. 37, n. 1, p. 11-19, may 2012.

DANIELS, J.; ROACH, B. T. Taxonomy and evolution. In: HEINZ, D. J. (Ed.). . Sugarcane improvement through breeding. Developments in crop science. Amsterdam ; New York: Elsevier, 1987.

DANON, A.; SANCHEZ COLL, N.; APEL, K. Cryptochrome-1-dependent execution of programmed cell death induced by singlet oxygen in Arabidopsis thaliana. Proceedings of the National Academy of Sciences, v. 103, n. 45 , p. 17036-17041, nov. 2006. 
DASH, P. K. et al. Genome-wide analysis of drought induced gene expression changes in flax (Linum usitatissimum). GM Crops \& Food, v. 5, n. 2, p. 106-119, april. 2014.

DOUBNEROVÁ HÝSKOVÁ, V. et al. Phosphoenolpyruvate carboxylase, NADP-malic enzyme, and pyruvate, phosphate dikinase are involved in the acclimation of Nicotiana tabacum L. to drought stress. Journal of Plant Physiology, v. 171, n. 5, p. 19-25, mar. 2014.

DUBOS, C. et al. MYB transcription factors in Arabidopsis. Trends in Plant Science, v. 15, n. 10, p. 573-581, oct. 2010.

ENDO, A. et al. Drought Induction of Arabidopsis 9-cis-Epoxycarotenoid Dioxygenase Occurs in Vascular Parenchyma Cells. PLANT PHYSIOLOGY, v. 147, n. 4, p. 1984-1993, aug. 2008.

FAROOQ, M. et al. Drought Stress in Plants: An Overview. In: AROCA, R. (Ed.). Plant Responses to Drought Stress. Berlin, Heidelberg: Springer Berlin Heidelberg, 2012. p. 1-33.

FRACASSO, A.; TRINDADE, L. M.; AMADUCCI, S. Drought stress tolerance strategies revealed by RNA-Seq in two sorghum genotypes with contrasting WUE. BMC Plant Biology, v. 16, n. 1, dec. 2016.

GONZÁLEZ, C. V. et al. Phytochrome B increases drought tolerance by enhancing ABA sensitivity in Arabidopsis thaliana: Phytochrome B, ABA sensitivity and drought tolerance. Plant, Cell \& Environment, v. 35, n. 11, p. 1958-1968, nov. 2012.

GRAÇA, J. P. DA et al. Physiological parameters in sugarcane cultivars submitted to water deficit. Brazilian Journal of Plant Physiology, v. 22, n. 3, p. 189-197, 2010.

GREGOROVÁ, Z. et al. Drought-Induced Responses of Physiology, Metabolites, and PR Proteins in Triticum aestivum. Journal of Agricultural and Food Chemistry, v. 63, n. 37, p. 8125-8133, sept. 2015.

GUO, M. et al. The Plant Heat Stress Transcription Factors (HSFs): Structure, Regulation, and Function in Response to Abiotic Stresses. Frontiers in Plant Science, v. 7, feb. 2016.

HANIN, M. et al. Plant dehydrins and stress tolerance: versatile proteins for complex mechanisms. Plant Signaling \& Behavior, v. 6, n. 10, p. 1503-1509, oct. 2011.

HASSAN, N. M. et al. Roles of dehydrin genes in wheat tolerance to drought stress. Journal of Advanced Research, v. 6, n. 2, p. 179-188, mar. 2015.

HAYANO-KANASHIRO, C. et al. Analysis of Gene Expression and Physiological Responses in Three Mexican Maize Landraces under Drought Stress and Recovery Irrigation. PLoS ONE, v. 4, n. 10, p. e7531, oct. 2009.

HONG, Y. et al. Overexpression of a Stress-Responsive NAC Transcription Factor Gene ONAC022 Improves Drought and Salt Tolerance in Rice. Frontiers in Plant Science, v. 7, jan. 2016.

HOPPER, D. W. et al. Transcriptomic network analyses of leaf dehydration responses identify highly connected ABA and ethylene signaling hubs in three grapevine species differing in drought tolerance. BMC Plant Biology, v. 16, n. 1, dec. 2016.

HOQUE, T. S. et al. Methylglyoxal: An Emerging Signaling Molecule in Plant Abiotic Stress Responses and Tolerance. Frontiers in Plant Science, v. 7, 13 sept. 2016.

HOSSAIN, M. A. et al. Molecular Mechanism of Heavy Metal Toxicity and Tolerance in Plants: Central Role of Glutathione in Detoxification of Reactive Oxygen Species and Methylglyoxal and in Heavy Metal Chelation. Journal of Botany, v. 2012, p. 1-37, 2012.

HOU, X. et al. A Novel ABA-Responsive TaSRHP Gene from Wheat Contributes to Enhanced Resistance to Salt Stress in Arabidopsis thaliana. Plant Molecular Biology Reporter, v. 31, n. 4, p. 791-801, aug. 2013. 
HU, H. et al. Overexpressing a NAM, ATAF, and CUC (NAC) transcription factor enhances drought resistance and salt tolerance in rice. Proceedings of the National Academy of Sciences, v. 103, n. 35, p. 12987-12992, aug. 2006.

HUANG, G.-T. et al. Signal transduction during cold, salt, and drought stresses in plants. Molecular Biology Reports, v. 39, n. 2, p. 969-987, feb. 2012.

JAIPHONG, T. et al. Effects of duration and combination of drought and flood conditions on leaf photosynthesis, growth and sugar content in sugarcane. Plant Production Science, v. 19, n. 3, p. 427-437, jul. 2016.

JIANG, J. et al. Construction and application of a co-expression network in Mycobacterium tuberculosis. Scientific Reports, v. 6, n. 1, sept. 2016.

KIDO, É. A. et al. New Insights in the Sugarcane Transcriptome Responding to Drought Stress as Revealed by Supersage. The Scientific World Journal, v. 2012, p. 1-14, 2012.

KIM, J. H.; CHOI, D.; KENDE, H. The AtGRF family of putative transcription factors is involved in leaf and cotyledon growth in Arabidopsis. The Plant Journal: For Cell and Molecular Biology, v. 36, n. 1, p. 94-104, oct. 2003.

KIM, J.-S. et al. Arabidopsis GROWTH-REGULATING FACTOR7 Functions as a Transcriptional Repressor of Abscisic Acid- and Osmotic Stress-Responsive Genes, Including DREB2A. The Plant Cell, v. 24, n. 8, p. 3393 3405, aug. 2012.

KISHOR, P. et al. Overexpression of [delta]-Pyrroline-5-Carboxylate Synthetase Increases Proline Production and Confers Osmotolerance in Transgenic Plants. Plant Physiology, v. 108, n. 4, p. 1387-1394, aug. 1995.

KIZIS, D.; PAGÈS, M. Maize DRE-binding proteins DBF1 and DBF2 are involved in rab17 regulation through the drought-responsive element in an ABA-dependent pathway. The Plant Journal: For Cell and Molecular Biology, v. 30, n. 6, p. 679-689, jun. 2002.

KNIGHT, H.; TREWAVAS, A. J.; KNIGHT, M. R. Calcium signalling in Arabidopsis thaliana responding to drought and salinity. The Plant Journal: For Cell and Molecular Biology, v. 12, n. 5, p. 1067-1078, nov. 1997.

KWON, Y. et al. Arabidopsis hot2 encodes an endochitinase-like protein that is essential for tolerance to heat, salt and drought stresses: Role of AtCTL1 in tolerance to abiotic stress. The Plant Journal, v. 49, n. 2, p. 184-193, jan. 2007.

LANGFELDER, P.; HORVATH, S. WGCNA: an R package for weighted correlation network analysis. BMC Bioinformatics, v. 9, n. 1, p. 559, 2008.

LEE, J.-H.; KIM, W. T. Regulation of abiotic stress signal transduction by E3 ubiquitin ligases in Arabidopsis. Molecules and Cells, v. 31, n. 3, p. 201-208, mar. 2011.

LEE, M. et al. Activation of a flavin monooxygenase gene YUCCA7 enhances drought resistance in Arabidopsis. Planta, v. 235, n. 5, p. 923-938, may 2012.

LEE, Y. et al. Abscisic Acid-Induced Phosphoinositide Turnover in Guard Cell Protoplasts of Vicia faba. Plant Physiology, v. 110, n. 3, p. 987-996, mar. 1996.

LEMBKE, C. G. et al. Identification of sense and antisense transcripts regulated by drought in sugarcane. Plant Molecular Biology, v. 79, n. 4-5, p. 461-477, jul. 2012.

LI, C. et al. Differential expression profiles and pathways of genes in sugarcane leaf at elongation stage in response to drought stress. Scientific Reports, v. 6, n. 1, sept. 2016a.

LI, W.-X. et al. The Arabidopsis NFYA5 Transcription Factor Is Regulated Transcriptionally and Posttranscriptionally to Promote Drought Resistance. THE PLANT CELL ONLINE, v. 20, n. 8, p. 2238-2251, 29 aug. 2008. 
LU, X. et al. RNA-seq Analysis of Cold and Drought Responsive Transcriptomes of Zea mays ssp. mexicana L. Frontiers in Plant Science, v. 8, 7 feb. 2017.

MAO, J. et al. From The Cover: A role for Arabidopsis cryptochromes and COP1 in the regulation of stomatal opening. Proceedings of the National Academy of Sciences, v. 102, n. 34, p. 12270-12275, aug. 2005.

MARCOLINO-GOMES, J. et al. Expression Patterns of GmAP2/EREB-Like Transcription Factors Involved in Soybean Responses to Water Deficit. PLoS ONE, v. 8, n. 5, p. e62294, may 2013.

MAZZUCOTELLI, E. et al. Abiotic stress response in plants: When post-transcriptional and post-translational regulations control transcription. Plant Science, v. 174, n. 4, p. 420-431, april. 2008.

MEDEIROS, D. B. et al. Physiological limitations in two sugarcane varieties under water suppression and after recovering. Theoretical and Experimental Plant Physiology, v. 25, n. 3, p. 213-222, 2013.

MEJIA-GUERRA, M. K. et al. From plant gene regulatory grids to network dynamics. Biochimica et Biophysica Acta (BBA) - Gene Regulatory Mechanisms, v. 1819, n. 5, p. 454-465, may 2012.

MIAO, Y. et al. An Arabidopsis Glutathione Peroxidase Functions as Both a Redox Transducer and a Scavenger in Abscisic Acid and Drought Stress Responses. THE PLANT CELL ONLINE, v. 18, n. 10, p. 2749-2766, 1 oct. 2006.

MÜLLER, M.; MUNNÉ-BOSCH, S. Ethylene Response Factors: A Key Regulatory Hub in Hormone and Stress Signaling. Plant Physiology, v. 169, n. 1, p. 32-41, sept. 2015.

PINHEIRO, C.; CHAVES, M. M. Photosynthesis and drought: can we make metabolic connections from available data? Journal of Experimental Botany, v. 62, n. 3, p. 869-882, jan. 2011.

PRABU, G. et al. Identification of Water Deficit Stress Upregulated Genes in Sugarcane. Plant Molecular Biology Reporter, v. 29, n. 2, p. 291-304, jun. 2011.

REZAEI, M. K. et al. Glutathione S-transferase (GST) family in barley: Identification of members, enzyme activity, and gene expression pattern. Journal of Plant Physiology, v. 170, n. 14, p. 1277-1284, sept. 2013.

RIBEIRO, M. S. et al. Partial rootzone drying in sugarcane (Saccharum officinarum L.): effects on gas exchange, growth and water use efficiency. Theoretical and Experimental Plant Physiology, v. 26, n. 3-4, p. 251-262, dec. 2014.

RODRIGUES, F. A. et al. Sugarcane genes differentially expressed during water deficit. Biologia Plantarum, v. 55, n. 1, p. 43-53, mar. 2011.

RODRIGUES, F. A.; DE LAIA, M. L.; ZINGARETTI, S. M. Analysis of gene expression profiles under water stress in tolerant and sensitive sugarcane plants. Plant Science, v. 176, n. 2, p. 286-302, feb. 2009.

RODRIGUEZ, M.; CANALES, E.; BORRAS-HIDALGO, O. Molecular aspects of abiotic stress in plants. [s.l: s.n.]. v. 22

SAHA, G. et al. Genome-wide identification and characterization of MADS-box family genes related to organ development and stress resistance in Brassica rapa. BMC Genomics, v. 16, n. 1, dec. 2015.

SAIBO, N. J. M.; LOURENÇO, T.; OLIVEIRA, M. M. Transcription factors and regulation of photosynthetic and related metabolism under environmental stresses. Annals of Botany, v. 103, n. 4, p. 609-623, feb. 2009.

SALES, C. R. G. et al. Photosynthetic and antioxidant responses to drought during sugarcane ripening. Photosynthetica, v. 53, n. 4, p. 547-554, dev. 2015.

SEKI, M. et al. Molecular responses to drought, salinity and frost: common and different paths for plant protection. Current Opinion in Biotechnology, v. 14, n. 2, p. 194-199, april. 2003.

SERIN, E. A. R. et al. Learning from Co-expression Networks: Possibilities and Challenges. Frontiers in Plant Science, v. 7, april. 2016. 
SHANNON, P. Cytoscape: A Software Environment for Integrated Models of Biomolecular Interaction Networks. Genome Research, v. 13, n. 11, p. 2498-2504, 1 nov. 2003.

SHEN, P.; HOUR, A.; LIU, L. D. Microarray meta-analysis to explore abiotic stress-specific gene expression patterns in Arabidopsis. Botanical Studies, v. 58, n. 1, dec. 2017.

SHINOZAKI, K.; YAMAGUCHI-SHINOZAKI, K. Gene Expression and Signal Transduction in Water-Stress Response. Plant Physiology, v. 115, n. 2, p. 327-334, oct. 1997.

SINGH, D.; LAXMI, A. Transcriptional regulation of drought response: a tortuous network of transcriptional factors. Frontiers in Plant Science, v. 6, 29 oct. 2015.

SINHA, A. K. et al. Mitogen-activated protein kinase signaling in plants under abiotic stress. Plant Signaling \& Behavior, v. 6, n. 2, p. 196-203, feb. 2011.

SIRCAR, S.; PAREKH, N. Functional characterization of drought-responsive modules and genes in Oryza sativa: a network-based approach. Frontiers in Genetics, v. 6, 30 jul. 2015.

SMITA, S. et al. Identification of conserved drought stress responsive gene-network across tissues and developmental stages in rice. Bioinformation, v. 9, n. 2, p. 72-78, 18 jan. 2013.

VAN DRIEL, R. The eukaryotic genome: a system regulated at different hierarchical levels. Journal of Cell Science, v. 116, n. 20, p. 4067-4075, 15 oct. 2003.

VILELA, B. et al. Casein Kinase 2 Negatively Regulates Abscisic Acid-Activated SnRK2s in the Core Abscisic AcidSignaling Module. Molecular Plant, v. 8, n. 5, p. 709-721, may 2015.

VISHWAKARMA, K. et al. Abscisic Acid Signaling and Abiotic Stress Tolerance in Plants: A Review on Current Knowledge and Future Prospects. Frontiers in Plant Science, v. 08, feb. 2017.

WANG, X. et al. Drought-Responsive Mechanisms in Plant Leaves Revealed by Proteomics. International Journal of Molecular Sciences, v. 17, n. 10, p. 1706, oct. 2016a.

WANG, Y. et al. A CBL-Interacting Protein Kinase TaCIPK2 Confers Drought Tolerance in Transgenic Tobacco Plants through Regulating the Stomatal Movement. PLOS ONE, v. 11, n. 12, p. e0167962, dec. 2016b.

XIONG, L. FIERY1 encoding an inositol polyphosphate 1-phosphatase is a negative regulator of abscisic acid and stress signaling in Arabidopsis. Genes \& Development, v. 15, n. 15, p. 1971-1984, aug. 2001.

XUE, H.-W.; CHEN, X.; MEI, Y. Function and regulation of phospholipid signalling in plants. Biochemical Journal, v. 421, n. 2, p. 145-156, jul. 2009.

YAMANE, K. et al. Bundle sheath chloroplasts of rice are more sensitive to drought stress than mesophyll chloroplasts. Journal of Plant Physiology, v. 160, n. 11, p. 1319-1327, jan. 2003.

YAO, X. et al. Overexpression of the aspartic protease ASPG1 gene confers drought avoidance in Arabidopsis. Journal of Experimental Botany, v. 63, n. 7, p. 2579-2593, april. 2012.

YOU, J.; CHAN, Z. ROS Regulation During Abiotic Stress Responses in Crop Plants. Frontiers in Plant Science, v. 6, dec. 2015.

YU, B.; XU, C.; BENNING, C. Arabidopsis disrupted in SQD2 encoding sulfolipid synthase is impaired in phosphatelimited growth. Proceedings of the National Academy of Sciences, v. 99, n. 8, p. 5732-5737, april. 2002.

YU, X. et al. The Cryptochrome Blue Light Receptors. The Arabidopsis Book, v. 8, p. e0135, jan. 2010.

ZENG, H. et al. Involvement of calmodulin and calmodulin-like proteins in plant responses to abiotic stresses. Frontiers in Plant Science, v. 6, 11 aug. 2015.

ZENG, Y.; YANG, T. RNA isolation from highly viscous samples rich in polyphenols and polysaccharides. Plant Molecular Biology Reporter, v. 20, n. 4, p. 417-417, 1 dec. 2002. 
ZHAN, X. et al. The Sulfoquinovosyltransferase-like Enzyme SQD2.2 is Involved in Flavonoid Glycosylation, Regulating Sugar Metabolism and Seed Setting in Rice. Scientific Reports, v. 7, n. 1, dec. 2017.

ZHANG, B.; HORVATH, S. A general framework for weighted gene co-expression network analysis. Statistical Applications in Genetics and Molecular Biology, v. 4, p. Article17, 2005.

ZHANG, J. et al. Molecular character of a phosphatase 2C (PP2C) gene relation to stress tolerance in Arabidopsis thaliana. Molecular Biology Reports, v. 40, n. 3, p. 2633-2644, mar. 2013.

ZHANG, S.-W. et al. Altered Architecture and Enhanced Drought Tolerance in Rice via the Down-Regulation of Indole-3-Acetic Acid by TLD1/OsGH3.13 Activation. PLANT PHYSIOLOGY, v. 151, n. 4, p. 1889-1901, dec. 2009 .

ZHOU, P. et al. Characterization of Gene Expression Associated with Drought Avoidance and Tolerance Traits in a Perennial Grass Species. PLoS ONE, v. 9, n. 8, p. e103611, aug. 2014.

ZHU, J.-K. S ALT AND D ROUGHT S TRESS S IGNAL T RANSDUCTION IN P LANTS. Annual Review of Plant Biology, v. 53, n. 1, p. 247-273, jun. 2002. 


\section{FINAL CONSIDERATIONS AND FUTURE PERSPECTIVES}

A comprehensive understanding of the organization, function and evolution of plant genes is essential to disentangle important biological processes and to advance crop engineering and breeding strategies, therefore, the ultimate goal in deciphering complex biological processes is the discovery of causal genes and regulatory mechanisms controlling the processes of interest (SERIN et al., 2016).

Several studies of plant responses to abiotic stresses have been done in the past years, but only a few try to integrate physiological and molecular changes caused by these stresses, especially drought. Most of all, it is difficult to find a work that integrates different strategies to interpret and obtain a deeper knowledge of the transcriptional changes happening in a plant during the stress. To our knowledge there are no works integrating both parameters for the study of the stress progression in a daily basis. Both physiology and transcriptomic data suggested that water privation for 4 and 6 days caused a moderated to severe stress, which was reversed by the rehydration period, characterizing the capacity of the plant to respond and recover from such stresses. After 6 days of water privation it was able to detect photochemical damage which was reflected on the transcripts detected.

Microarray allowed the identification of 7,867 SAS with $\mathrm{FC} \geq 2$ and $\mathrm{FC} \leq 0.5$ and 585 considered differentially expressed by the HTSelf method. The update in the annotation from SUCEST database allowed the decrease in the number of unknown or hypothetical proteins, and helped in the standardization of the annotation. Therefore, analysis such as Fisher's Enrichment test could be performed along with the identification of orthologus groups. The annotation of DEGs determined by the HTSelf allowed the determination that classes related to photosynthesis were enriched only after 6 days of stress on the down-regulated genes and also that classes related to root growth were down-regulated during the stress.

This work also allowed the identification of LEA proteins, ABA related factors and transcription factors among other genes involved with classical drought responses, along with the observation of some genes altered in different drought experiments, such as Dehydrin and SAPK1 which can be interesting targets for transgenic approachs. Furthermore, pathview analysis showed the emphasis of plant metabolism on sensing and transducing the signal in the beginning of the stress and functionally reacting to it once the stress is severe. In addition, the crosstalk between stresses and between drought and lignin biosynthesis could be identified. Pathview analysis using microarray data shed light on some important pathways with different responses on leaves and roots, such as galactose and phenylpropanoid metabolism.

Interestingly in the case of phenylpropanoids biosynthesis, transcriptome analysis indicated the difference in expression of genes related to lignin metabolism, but quantification of the metabolite did not indicate significant changes, probably because the stress was not severe enough or because the quantification allowed the determination of only total lignin and not specific variants. Sugar metabolism appeared to be essential for roots responses to osmotic stress, as well as modification of lipids metabolism in the leaves. After re-watering, protein synthesis and turnover seems to have a fundamental role for the plants recovery.

Moreover, although it seems to be a systemic response of the plant to the stress, there are some pathways, such as the antioxidant and DNA repair related ones, that are preferentially expressed either in leaves or in roots. This could mean that leaves tend to avoid damage, while roots tend repair it. The up-regulation of differentially expressed genes in leaves might mean that in this tissue there is a tendency to stimulate gene expression, due maybe to the activation of new routes to respond and tolerate drought. In roots, the repression of most of the genes seems to show 
an opposite tendency, which could be that roots are shutting down some processes, as, exemplified by the downregulation of cell division and expansion related genes.

Furthermore, the down-regulation of aquaporins may be a response of the plant to increase roots hydraulic resistance and avoid loss of water to the soil. The expression of classical drought response pathways, such as proline, $\mathrm{ABA}$ and lipid metabolism, as well as the stimulation of less known routes, that are also related to important functions during drought responses, like lipoic acid pathway, show the agreement between the results found and the hypothesis of an attempt by the plant to tolerate the stress and recover from it after rehydration. The combination of data obtained from differentially expressed and significantly expressed genes allowed a global view of what seems to be happening in the plant during water stress and rehydration, such as the up-regulation of ABA-dependent and independent pathways, ethylene, lipid metabolism, DNA repair, osmolytes and terpenoids pathways, along with the down-regulation of aquaporins and gibberellin. Opposing to that, rehydration seem to repress ABA and ethylene biosynthesis.

RNA-Seq allowed the assembly of a huge amount of transcripts, both through de novo RNA-Seq assembly and using a reference genome. RNA-Seq de novo analysis corroborates with some conclusions obtained from microarray and allowed the observation that some terms from classification are exclusive for up or down-regulated transcritps, while terms such as "Transcription" and "Signal transduction Mechanisms" are important in both groups. In the case of using the reference genome, this work shed light on the possible role for a variety of hormones in leaves responses to drought, such as jasmonic acid and brassinosteroids. Also ABA seems to play a central function in water stress responses no matter the plant tissue.

The search of miRNA sequences on the differentially expressed genes lead to the identification of interesting classes of miRNA and shows the importance of studying sugarcane miRNAs differentially expressed on diverse sugarcane varieties and plant tissue during stresses.

The analysis of drought progression experiment, show a daily decrease in the parameters of photosynthesis, stomatal conductance and transpiration. These values were close to 0 on the seventh day of stress, but 24 hours after re-watering plants already had these parameters back to normal values. qRT-PCR using characteristic drought related genes, show that their expression starts to increase after 3 or 4 days of stress and then, begin to decrease after the 7 th day without water, indicating that maybe in this point, when physiology parameters indicate a severe stress, the plant is starting the senescence process. Furthermore, a couple of genes with similarity on their expression during drought progression also appeared in the same co-expression modules.

The analysis of co-expression networks and their relationship with physiological parameters of interest allowed the determination of three interesting modules, which contained Top nodes related to both protection of photosynthetical membranes and antioxidant responses, and shows that the group in successfully stablishing a pipeline for the analysis of Co-Expression networks. Despite that, since the experiments used in this analysis were very diverse, several genes were excluded on the analysis because did not reach the cut off value. Therefore, for future experiments it will be interesting to use the same pattern of experiment in different varieties.

Overall, the results of our project could provide a complete and comprehensive view of sugarcane response to one of the most affecting abiotic stress for this crop. For the next steps, the analysis of qRT-PCR using primers for genes from auxin and ethylene biosynthesis and signaling pathways will be performed in order to understand their pattern of expression and correlate the results with their co-expression modules. Furthermore, the interpretation of RNA-Seq data will be improved and the analysis will focus on the groups in common between leaves and roots samples as well as on the search for transcription factors sequences differentially expressed during water stress, aiming to select targets on the new assembly of the sugarcane genome for future studies. 


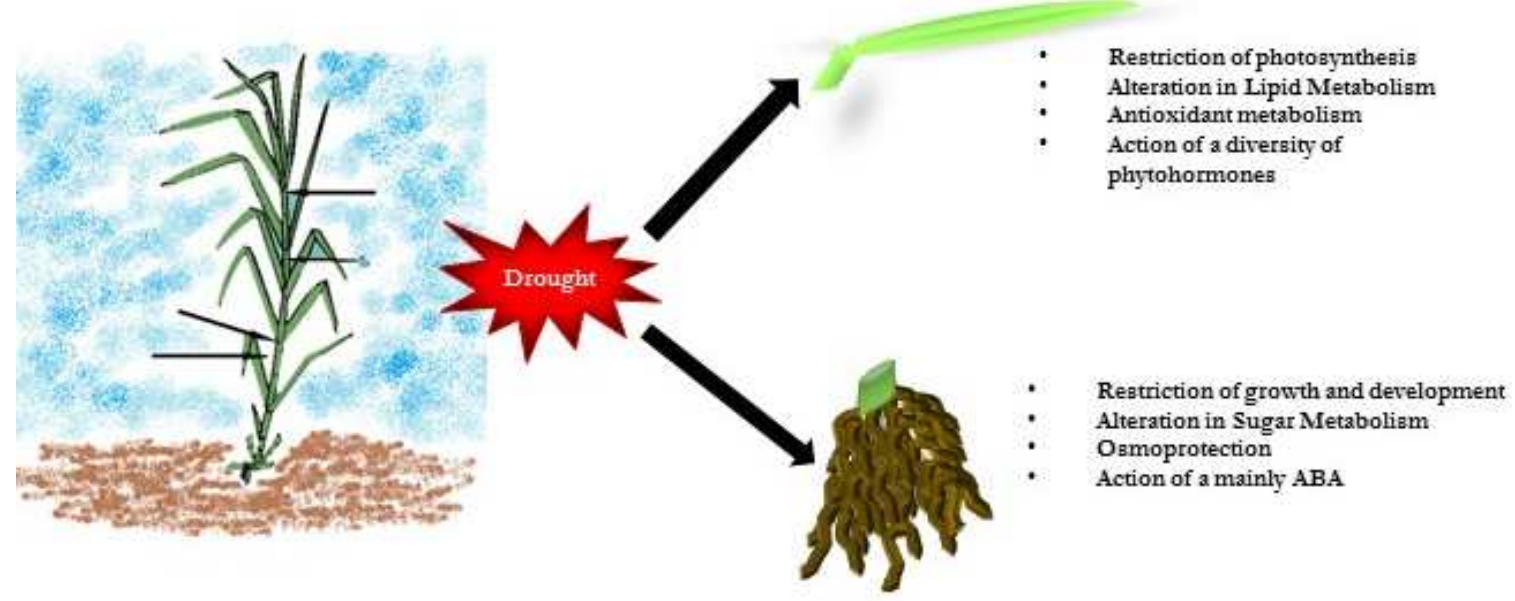

Figure 60. Summary of sugarcane leaves and roots responses to water stress as detected in this work 